\title{
GEOSTATISTICAL ANALYSIS OF SPACE VARIATION IN UNDERGROUND WATER VARIOUS QUALITY PARAMETERS IN KŁODZKO WATER INTAKE AREA (SW PART OF POLAND)
}

\author{
BARBARA NAMYSŁOWSKA-WILCZYŃSKA \\ Faculty of Civil Engineering, Wrocław University of Science and Technology, \\ Wybrzeże Wyspiańskiego 27, 50-370 Wrocław, Poland, e-mail: Barbara.Namyslowska-Wilczynska@pwr.edu.pl
}

\begin{abstract}
This paper presents selected results of research connected with the development of a (3D) geostatistical hydrogeochemical model of the Kłodzko Drainage Basin, dedicated to the spatial variation in the different quality parameters of underground water in the water intake area (SW part of Poland). The research covers the period 2011-2012. Spatial analyses of the variation in various quality parameters, i.e., contents of: iron, manganese, ammonium ion, nitrate ion, phosphate ion, total organic carbon, $\mathrm{pH}$ redox potential and temperature, were carried out on the basis of the chemical determinations of the quality parameters of underground water samples taken from the wells in the water intake area. Spatial variation in the parameters was analyzed on the basis of data obtained (November 2011) from tests of water taken from 14 existing wells with a depth ranging from 9.5 to $38.0 \mathrm{~m}$ b.g.l. The latest data (January 2012) were obtained (gained) from 3 new piezometers, made in other locations in the relevant area. A depth of these piezometers amounts to $9-10 \mathrm{~m}$.

Data derived from 14 wells (2011) and 14 wells +3 piezometers (2012) were subjected to spatial analyses using geostatistical methods. The evaluation of basic statistics of the quality parameters, including their histograms of distributions, scatter diagrams and correlation coefficient values $r$ were presented. The directional semivariogram function $\gamma(h)$ and the ordinary (block) kriging procedure were used to build the 3D geostatistical model. The geostatistical parameters of the theoretical models of directional semivariograms of the water quality parameters under study, calculated along the wells depth (taking into account the terrain elevation), were used in the ordinary (block) kriging estimation.

The obtained results of estimation, i.e., block diagrams allowed us to determine the levels of increased values of estimated averages $Z^{*}$ of underground water quality parameters.
\end{abstract}

Key words: underground water, hydrogeochemistry, quality parameters, space variation, geostatistics

\section{INTRODUCTION}

The inhabitants of Kłodzko are supplied with water by a central water main drawing off water from underground intakes in Quaternary formations [2], [6]. Water is drawn off (siphoned or pumped) via dug and drilled wells located on both sides of the Kłodzko Nysa river. Generally, the depth of the wells ranges from $9.5 \mathrm{~m}$ to $38.0 \mathrm{~m}$. The water abstraction depth (difference between the terrain elevation and the dynamic water table level) is ranged from $276-286 \mathrm{~m}$ a.s.l., with an average of $282.05 \mathrm{~m}$ a.s.l. Dynamic water table level is contained between $6.22-16.44 \mathrm{~m}$ b.g.l., with a mean value of $9.64 \mathrm{~m}$ b.g.l.

The Quaternary formations (Pleistocene deposits the Cracow and Central Poland glaciation period, Quaternary - Holocen formations) are deposited directly on crystalline metamorphic rocks. Boreholes have shown that the oldest formations are Old Palaeozoic greenstones or their weathering waste, underlaying the Quaternary sand-gravel deposits. Greenstones were found in the deepest boreholes, maximally to $38 \mathrm{~m}$ below the terrain surface, but generally their roof is deposited at 20-36 m, coming closer $(6-10 \mathrm{~m})$ to the surface towards the edges of the formed through. The roof forms the uneven below-Quaternary surface of the Kłodzko Nysa valley. The profile of the geological structure in the Kłodzko water intake was presented in detail in the works [4], [6], [12].

The height of the Kłodzko area of underground water intake being analyzed varies in the range of 287.22-297.70 $\mathrm{m}$ a.s.1. with an average reaching $291.68 \mathrm{~m}$ a.s.l. The analyzed 22 wells are located in the terrain belonging to the Regional Board of Regional Water Management (RZGW) and Kłodzko Water Supply Systems [2], [6]. These wells were made in the years 1954-1998. The subject of spatial analyses were 
data coming from 14 wells which were selected from the above mentioned 22 wells, and also concerning the well collecting siphon. In the water intake area, in the region of Kłodzko the 3 piezometers (P1, P2, P3) were drilled a depth up to of 9-10 m, on the land owned by to the Agricultural Real Estate Agency ANR, RZGW and WKL (Polish names), in January 2012 [2], [6].

Kłodzko Valley is bounded on the N Valley Ścinawka and Bardzkie Mountains, on the S the Śnieżnik Mountains and Trench Upper Nysa, while on the W the Table Mountains.

Geologically shows the structure channeled, the axis of which extends along the NW-SE. By Kłodzko Valley flows Glatzer Nysa, which together with its tributaries forms a dense hydrological network. There are 4 main catchments representing 4 mountain groups in this area. They are built of crystalline rocks, i.e., granite-gneiss, mica schists and crystalline limestones.

In the article geostatistical methods were used, previously applied in spatial modelling, estimating and forecasting of the phenomena emerging in 2D and 3D systems, including areas such as geology and mining, environment protection, energy and economy [5], and also hydrogeology [6]-[14].

The variation in different underground water quality parameters, such as iron $\mathrm{Fe}^{++}$, manganese $\mathrm{Mn}^{++}$, ammonium ion $\mathrm{NH}_{4}^{+}$content, nitrate anion $\mathrm{NO}_{3}^{-}$ content, phosphate anion $\mathrm{PO}_{4}^{-3}$ content, total organic carbon (TOC), $\mathrm{pH}$ redox potential and temperature ${ }^{\circ} \mathrm{C}$, in the Kłodzko water intake area (the SW part of Poland) (Fig. 1) was subjected to spatial analyses, using geostatistical methods, i.e., directional semivariogram function and an ordinary (block) kriging [1], [3], [5], [15], [16].

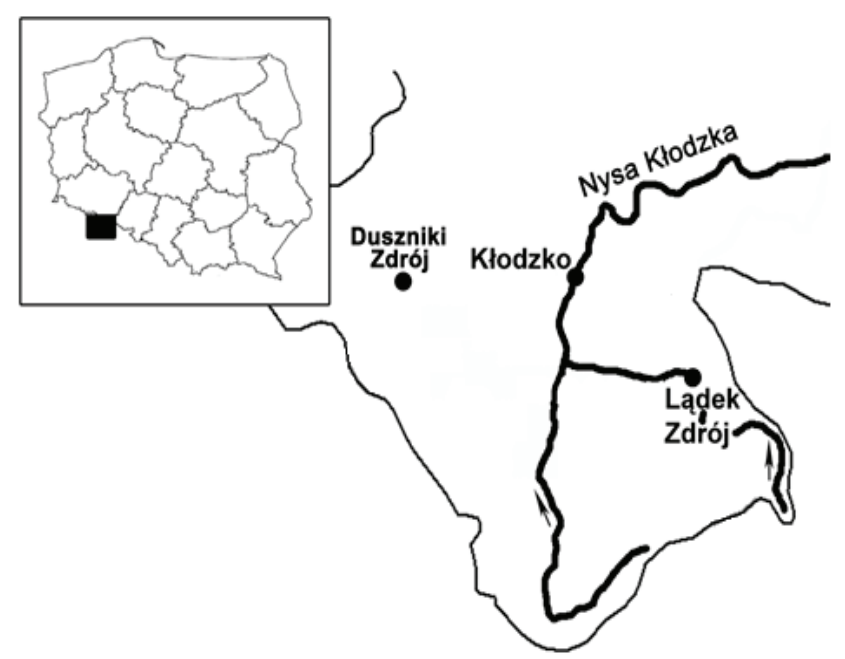

Fig. 1a. Location catchment in the Kłodzko Valley area (SW part of Poland) [2], [6], [14]

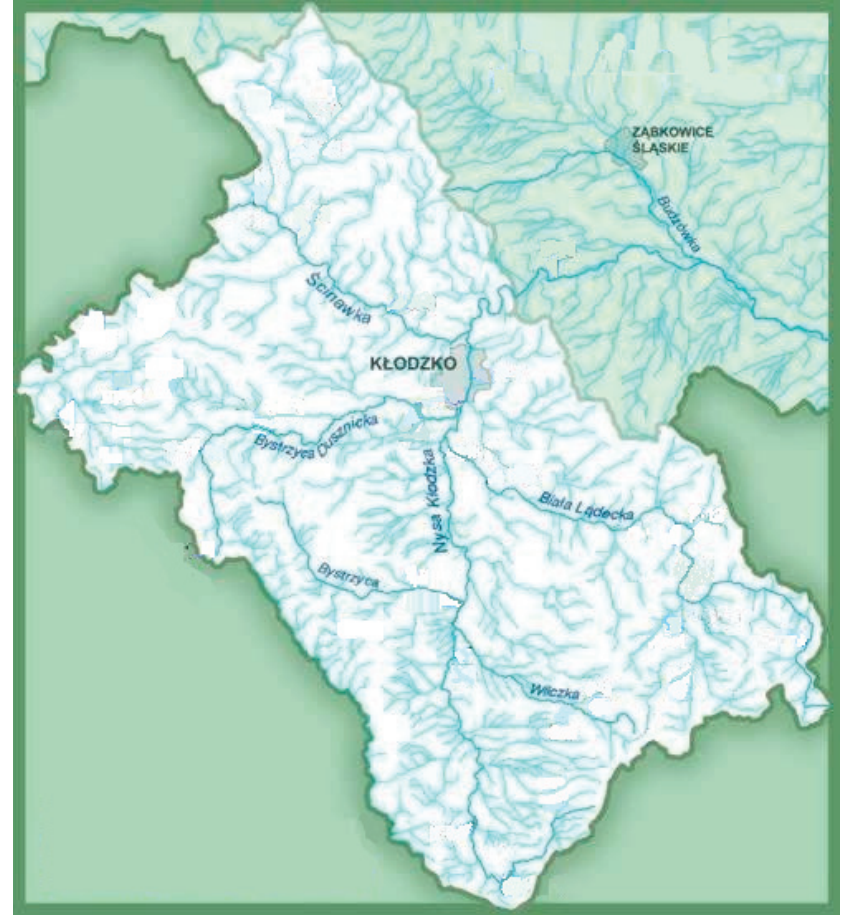

Fig. 1b. The catchment area of the river of Nysa Kłodzka (SW part of Poland); Characteristics of the balance sheet catchment area of the river Nysa Kłodzka, according to Jerzy Kondracki

(J. Kondracki, Geografia regionalna Polski, wyd. 3 uzup., Wydaw. Naukowe PWN, Warszawa, 2002)

The selected results of modelling and estimating the $\mathrm{Fe}^{++}$content and the $\mathrm{Mn}^{++}$content in the underground water in 22 wells and in 3 piezometers and in the area considered for the years 1977-2012, as well as in the treated water and in the supply network water for the years 2007-2011 are reported in the author's previous papers published in scientific journals and conference proceedings [7]-[14].

Spatial and space-time analyses of quality parameters of underground water were carried out for several analytical variants, taking into account data from 22 wells, i.e., 14 wells, 3 piezometers and 14 wells +3 piezometers located in the Kłodzko water intake area [6].

In the present study, the results of chemical analyses (covering 8 quality parameters) of underground water samples taken from 14 wells selected from the 22 wells in the Kłodzko water intake area and then from 3 new piezometers installed there and further 14 wells and 3 piezometers constituted the input for geostatistical investigations ${ }^{1}$. The chemical analyses were car-

${ }^{1}$ These are selected results of research carried out as part of the National Centre for Research \& Development grant No. N09-0036-10/2011, entitled "The technology of the biochemical remediation and storage of surface waters in underground hydrogeological structures for municipal water intakes in river valleys" funded by the Ministry of Science and Higher Education in War- 
ried out on 15.11.2011 (14 wells) and 22-23.01.2012 (3 new piezometers) and presented in [6].

The geostatistical analyses ${ }^{2}$ were carried out using databases containing the values of the quality parameters considered together with coordinates $X, Y$ and $Z$ (well depth - vertical direction of study).

The variation in the geostatistical water quality parameters was analysed downwards the depth of wells (along the $Z$-axis), using the directional semivariogram function $\gamma(h)$ and next the ordinary (block) kriging technique. The theoretical basis of the geostatistical methods can be found in the scientific works, e.g., [1], [3], [5], [15]-[17]. The analyses were preceded by the evaluation of the statistical parameters, i.e., basic statistics and the investigation of the correlation coefficients $r$ between the underground water quality parameters.

Selected results of the spatial analyses performed were presented in the EGU 2016 European Geosciences Union - General Assembly, Austria Center Vienna (17-22 April 2016), at the Session HS3.2/NH1.26 "Spatio-temporal and/or geostatistical analysis of hydrological events, extremes, and related hazards" (Thursday, 21 Apr. 2016).

\section{EVALUATION OF BASIC STATISTICS OF UNDERGROUND QUALITY PARAMETERS IN KLODZKO WATER INTAKE AREA}

An increased concentration of $\mathrm{Fe}^{++}$content in some wells occurred. All water samples contained elevated $\mathrm{Mn}^{++}$content, many times exceeding the permissible concentrations in water intended for human consumption [2], [6], [12]. Water samples from the wells tested were characterized by higher content of $\mathrm{Mn}^{++}$than $\mathrm{Fe}^{++}$in some subareas (central part of the study area) and other subareas had to deal with the opposite situation, i.e., with higher concentrations of $\mathrm{Fe}^{++}$than $\mathrm{Mn}^{++}$, moreover also high values of $\mathrm{pH}$ potential in the same location area.

Exemplary base maps for some of the water quality parameters, namely $\mathrm{Fe}^{++}$content, $\mathrm{Mn}^{++}$content and

saw; project "Water" (2011-2016). Research task 3 entitled "Identification and hydrogeochemical models of the Kłodzko Drainage Area (2011-2012)" (2012) [6].

${ }^{2}$ Geostatistical spatial analyses were performed using the computing programmes included in the ISATIS software package - version 2015.3 (Isatis oftware User's Guide, ISATIS, Isatis version 2015, Ecole des Mines de Paris, Centre de Geostatistique, Fontainebleau, Geovariances, Avon Cedex, France, 2015).
$\mathrm{pH}$ redox potential, for the analysed configuration, the 14 wells + the 3 piezometers are shown respectively in Figs. 2a-2c.

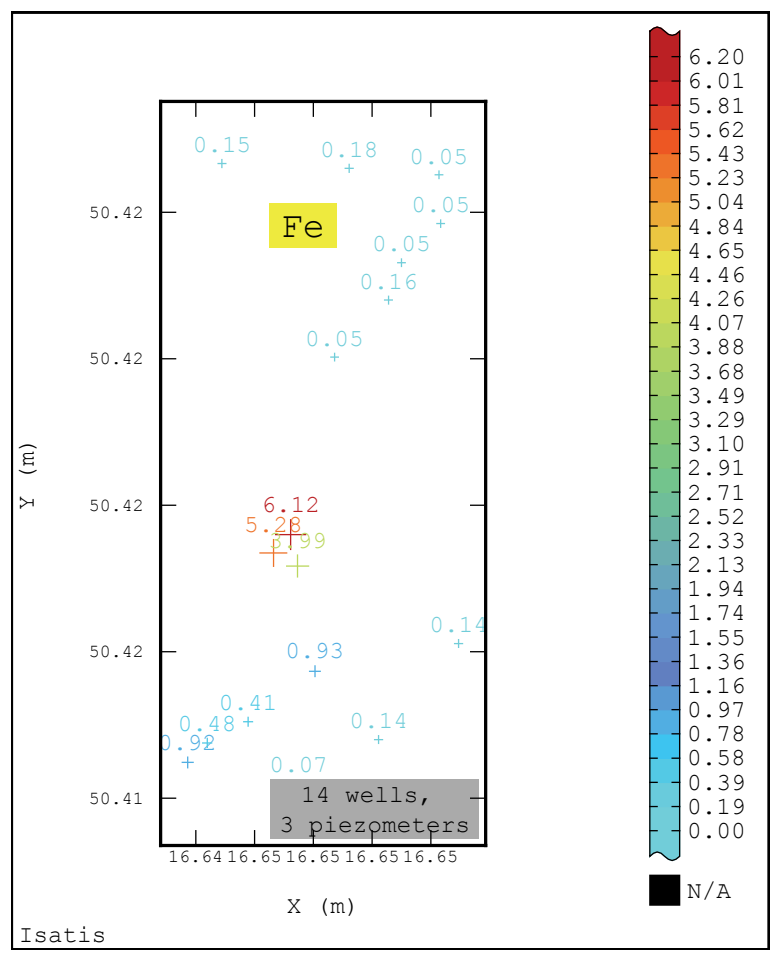

Fig. 2a. Base map of iron $\mathrm{Fe}^{++}\left[\mathrm{g} \mathrm{Fe}^{++} / \mathrm{m}^{3}\right]$ content in underground water for water intake area of Kłodzko (SW part of Poland); data coming from 14 wells +3 piezometers

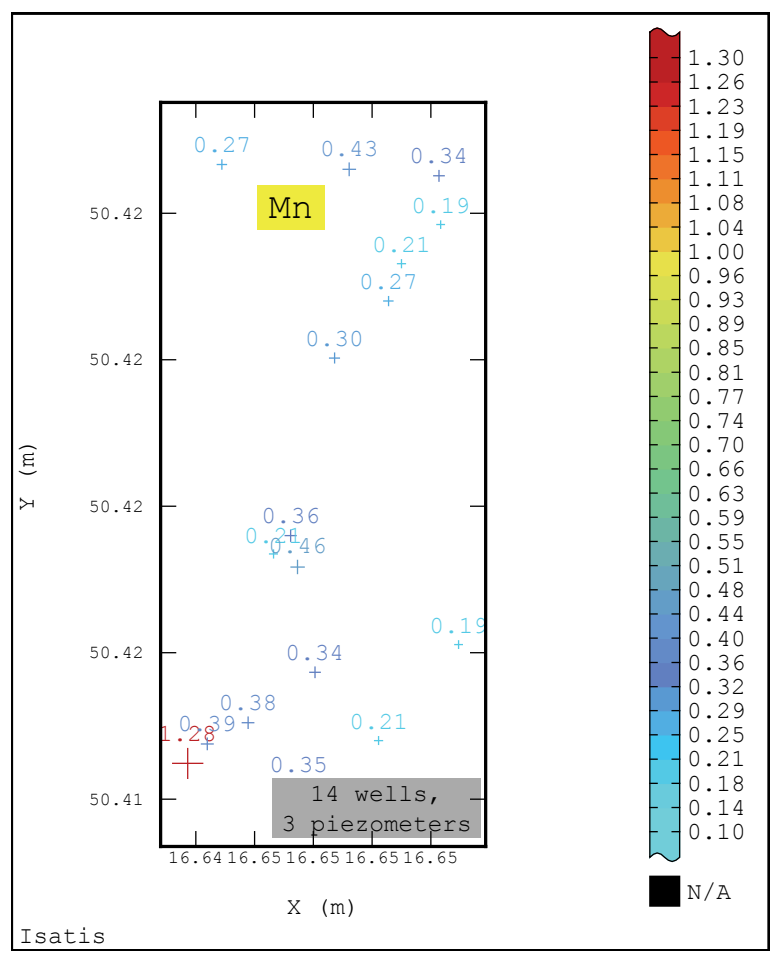

Fig. 2b. Base map of manganese $\mathrm{Mn}^{++}$content $\left[\mathrm{g} \mathrm{Mn}^{++} / \mathrm{m}^{3}\right]$ in underground water for water intake area of Kłodzko (SW part of Poland); data coming from 14 wells +3 piezometers 


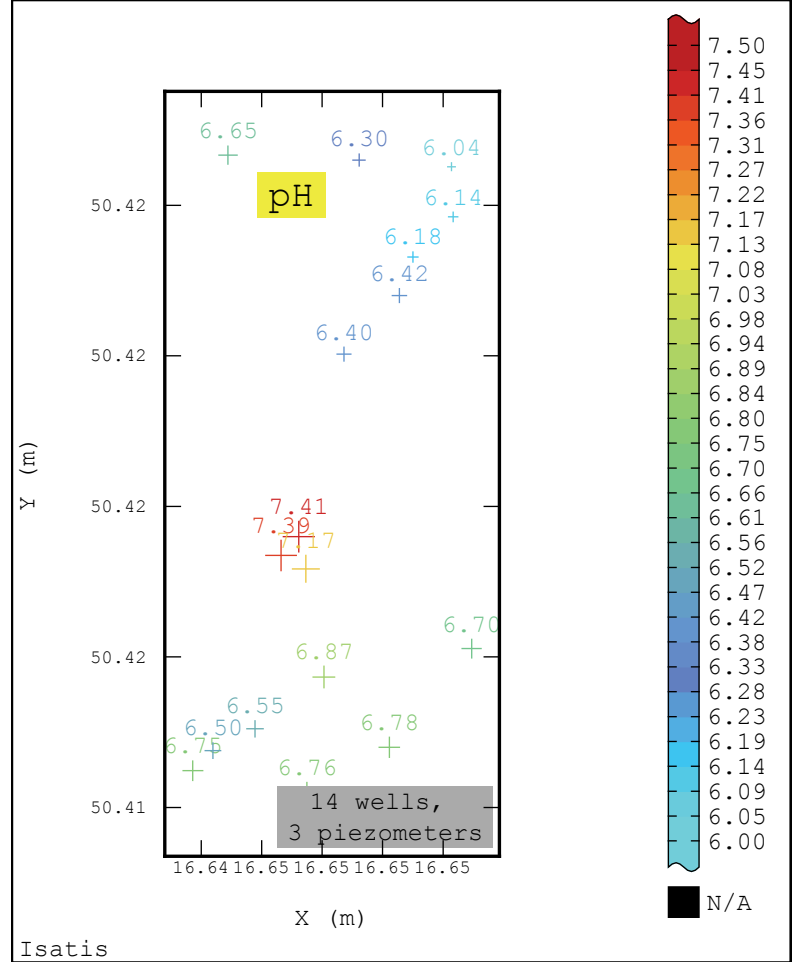

Fig. 2c. Base map of oxidation-reduction potential $\mathrm{pH}$ in underground water for water intake area of Kłodzko (SW part of Poland); data coming from 14 wells +3 piezometers
The basic statistics of the underground water quality parameters, such as minima $X_{\min }$, maxima $X_{\max }$, averages $\bar{X}$, standard deviations $S$ and variation coefficients $V$, were evaluated on the basis of the data for the 14 wells and then the 14 wells, including the 3 piezometers (Tables 1-2). For comparison, also the estimates of the statistical parameters of $\mathrm{Fe}^{++}$content and $\mathrm{Mn}^{++}$content, which were presented in earlier papers [7]-[10], [13], [14], are included in Table 1.

In the underground water coming from 14 wells located in the area of the intake Kłodzko, studied on 15.11.2011, there were found the limit permissible values by $\min$, max values and average contents of manganese $\mathrm{Mn}^{++}$, as well as the max and the average content of iron $\mathrm{Fe}^{++}$and as the max $\mathrm{NH}_{4}^{+}$ion content approaches the limit value of this parameter (Table 1).

However, in the 3 piezometers made in water intake area in Kłodzko on 23.01.2012, extremely high $\mathrm{Fe}^{++}$content was recorded, which refers to the min, max and average of this parameter (Table 2). These statistics of $\mathrm{Mn}^{++}$content also greatly exceed the limit values of this element. There can be observed extremely higher $\mathrm{pH}$ of the water analyzed for 3 piezometers (Table 2), compared with the results of chemical analyses concerning the 14 wells (Table 1).

Table 1. Basic statistics of quality parameters of underground water in the intake area in the region of Kłodzko (14 wells) (year 2011)

\begin{tabular}{|c|c|c|c|c|c|c|}
\hline $\begin{array}{l}\text { Parameter } \\
\text { analyzed }\end{array}$ & $\begin{array}{l}\text { Sample } \\
\text { size } \\
n\end{array}$ & $\begin{array}{c}\text { Minimal } \\
\text { value } \\
X_{\min }\end{array}$ & $\begin{array}{c}\text { Maximal } \\
\text { value } \\
X_{\max }\end{array}$ & $\begin{array}{c}\text { Average } \\
\text { value } \\
\bar{X}\end{array}$ & $\begin{array}{c}\text { Standard } \\
\text { deviation } \\
S\end{array}$ & $\begin{array}{c}\text { Variation } \\
\text { coefficient } \\
V[\%]\end{array}$ \\
\hline $\begin{array}{l}\text { Oxidation-reduction } \\
\text { potential } \mathrm{pH}\end{array}$ & 14 & 6.04 & 6.87 & 6.50 & 0.25 & 3.92 \\
\hline $\begin{array}{l}\text { Temperature }\left[{ }^{\circ} \mathrm{C}\right] \\
\text { [degrees] }\end{array}$ & 14 & 7.30 & 9.80 & 7.97 & 0.63 & 7.88 \\
\hline $\begin{array}{l}\text { Ammonium ion } \mathrm{NH}_{4}^{+} \\
\text {content }\left[\mathrm{g} \mathrm{NH}_{4}^{+} / \mathrm{m}^{3}\right]\end{array}$ & 14 & 0.08 & 0.47 & 0.15 & 0.11 & 71.80 \\
\hline $\begin{array}{l}\text { Nitrate ion } \mathrm{NO}_{3}^{-} \\
\text {content }\left[\mathrm{g} \mathrm{NO} \mathrm{NO}_{3}^{-} / \mathrm{m}^{3}\right]\end{array}$ & 14 & 0.13 & 3.48 & 0.88 & 0.82 & 93.74 \\
\hline $\begin{array}{l}\text { Phosphate ion } \mathrm{PO}_{4}^{-3} \\
\text { content }\left[\mathrm{g} \mathrm{PO}_{4}^{-3} / \mathrm{m}^{3}\right]\end{array}$ & 14 & 0.06 & 0.24 & 0.11 & 0.05 & 43.75 \\
\hline $\begin{array}{l}\text { Total organic coal C } \\
\text { (OWO) content } \mathrm{C} \\
{\left[\mathrm{g} \mathrm{C}^{3} \mathrm{~m}^{3}\right]}\end{array}$ & 14 & 0.71 & 1.54 & 1.09 & 0.18 & 16.69 \\
\hline $\begin{array}{l}\text { Iron } \mathrm{Fe}^{++} \text {content } \\
{\left[\mathrm{g} \mathrm{Fe}^{++} / \mathrm{m}^{3}\right]}\end{array}$ & 14 & 0.05 & 0.93 & 0.27 & 0.30 & 109.50 \\
\hline $\begin{array}{l}\text { Manganese } \mathrm{Mn}^{++} \\
\text {content }\left[\mathrm{g} \mathrm{Mn}^{++} / \mathrm{m}^{3}\right]\end{array}$ & 14 & 0.19 & 1.28 & 0.37 & 0.26 & 71.75 \\
\hline
\end{tabular}

Permissible values of quality parameters of water: Ammonium ion $\mathrm{NH}_{4}^{+}$content $<0.50\left[\mathrm{~g} \mathrm{NH}_{4}^{+} / \mathrm{m}^{3}\right]$, Nitrate ion $\mathrm{NO}_{3}^{-}$content $\mathrm{NO}_{3}^{-}\left[50 \mathrm{~g} \mathrm{NO}_{3}^{-} / \mathrm{m}^{3}\right]$, Phosphate ion $\mathrm{PO}_{4}^{-3}$ content - in non-normalized drinking water, Total organic coal $\mathrm{C}(\mathrm{OWO})$ content $\left[5 \mathrm{~g} \mathrm{C}^{3} \mathrm{~m}^{3}\right]$, Iron $\mathrm{Fe}^{++}$content $<0.20\left[\mathrm{~g} \mathrm{Fe}^{++} / \mathrm{m}^{3}\right]$, Manganese $\mathrm{Mn}^{++}$content $<0.05\left[\mathrm{~g} \mathrm{Mn}^{++} / \mathrm{m}^{3}\right]$. 
Table 2. Basic statistics of quality parameters of underground water in the intake area in the region of Kłodzko (3 piezometers) (year 2012)

\begin{tabular}{|l|c|c|c|c|c|c|}
\hline \multicolumn{1}{|c|}{$\begin{array}{c}\text { Parameter } \\
\text { analyzed }\end{array}$} & $\begin{array}{c}\text { Sample } \\
\text { size } n\end{array}$ & $\begin{array}{c}\text { Minimal } \\
\text { value } \\
X_{\min }\end{array}$ & $\begin{array}{c}\text { Maximal } \\
\text { value } \\
X_{\max }\end{array}$ & $\begin{array}{c}\text { Average } \\
\text { value } \\
\bar{X}\end{array}$ & $\begin{array}{c}\text { Standard } \\
\text { deviation } \\
S\end{array}$ & $\begin{array}{c}\text { Variation } \\
\text { coefficient } \\
V[\%]\end{array}$ \\
\hline $\begin{array}{l}\mathrm{Iron} \mathrm{Fe}^{++} \text {content } \\
{\left[\mathrm{g} \mathrm{Fe}^{++} / \mathrm{m}^{3}\right]}\end{array}$ & 3 & 3.9900 & 6.1200 & 5.1300 & 0.8760 & 17.08 \\
\hline $\begin{array}{l}\mathrm{Manganese} \mathrm{Mn}^{++} \text {content } \\
{\left[\mathrm{g} \mathrm{Mn}^{++} / \mathrm{m}^{3}\right]}\end{array}$ & 3 & 0.2100 & 0.4600 & 0.3433 & 0.1027 & 29.92 \\
\hline Oxidation-reduction $\mathrm{pH}$ & 3 & 7.1700 & 7.4100 & 7.3233 & 0.1087 & 1.48 \\
\hline
\end{tabular}

Permissible values of quality parameters of water: Ammonium ion $\mathrm{NH}_{4}^{+}$content $<0.500\left[\mathrm{~g} \mathrm{NH}_{4}^{+} / \mathrm{m}^{3}\right.$ ], Nitrate ion $\mathrm{NO}_{3}^{-}$content $\mathrm{NO}_{3}^{-}\left[50 \mathrm{~g} \mathrm{NO}_{3}^{-} / \mathrm{m}^{3}\right]$, Phosphate ion $\mathrm{PO}_{4}^{-3}$ content - in non-normalized drinking water, - Total organic coal $\mathrm{C}(\mathrm{OWO})$ content $\left[5 \mathrm{~g} \mathrm{C}^{3} \mathrm{~m}^{3}\right]$, Iron $\mathrm{Fe}^{++}$content $<0.200\left[\mathrm{~g} \mathrm{Fe}^{++} / \mathrm{m}^{3}\right]$, Manganese $\mathrm{Mn}^{++}$content $<0.050\left[\mathrm{~g} \mathrm{Mn}^{++} / \mathrm{m}^{3}\right]$.

Table 3. Basic statistics of quality parameters of underground water in the intake area in the region of Kłodzko (14 wells + 3 piezometers) (years: 2011-2012)

\begin{tabular}{|l|c|c|c|c|c|c|}
\hline \multicolumn{1}{|c|}{$\begin{array}{c}\text { Parameter } \\
\text { analyzed }\end{array}$} & $\begin{array}{c}\text { Sample } \\
\text { size } n\end{array}$ & $\begin{array}{c}\text { Minimal } \\
\text { value } \\
X_{\min }\end{array}$ & $\begin{array}{c}\text { Maximal } \\
\text { value } \\
X_{\max }\end{array}$ & $\begin{array}{c}\text { Average } \\
\text { value } \\
\bar{X}\end{array}$ & $\begin{array}{c}\text { Standard } \\
\text { deviation } \\
S\end{array}$ & $\begin{array}{c}\text { Variation } \\
\text { coefficient } \\
V[\%]\end{array}$ \\
\hline $\begin{array}{l}\text { Oxidation-reduction } \\
\text { potential } \mathrm{pH}\end{array}$ & $14+3$ & 6.04 & 7.41 & 6.65 & 0.39 & 5.89 \\
\hline $\begin{array}{l}\mathrm{Iron} \mathrm{Fe} \\
{\left[\mathrm{g} \mathrm{Fe}^{++} / \mathrm{m}^{3}\right]}\end{array}$ & $14+3$ & 0.05 & 6.12 & 1.13 & 1.91 & 169.19 \\
\hline $\begin{array}{l}\mathrm{Manganese} \mathrm{Mn}^{++} \text {content } \\
{\left[\mathrm{g} \mathrm{Mn}^{++} / \mathrm{m}^{3}\right]}\end{array}$ & $14+3$ & 0.19 & 1.28 & 0.36 & 0.24 & 67.00 \\
\hline
\end{tabular}

Permissible values of quality parameters of water: Ammonium ion $\mathrm{NH}_{4}^{+}$content $<0.500$ [ $\mathrm{g} \mathrm{NH}_{4}^{+} / \mathrm{m}^{3}$ ], Nitrate ion $\mathrm{NO}_{3}^{-}$content $\mathrm{NO}_{3}^{-}\left[50 \mathrm{~g} \mathrm{NO}_{3}^{-} / \mathrm{m}^{3}\right]$, Phosphate ion $\mathrm{PO}_{4}^{-3}$ content - in non-normalized drinking water, Total organic coal $\mathrm{C}$ (OWO) content $\left[5 \mathrm{~g} \mathrm{C}^{3} \mathrm{~m}^{3}\right]$, Iron $\mathrm{Fe}^{++}$content $<0.200\left[\mathrm{~g} \mathrm{Fe}^{++} / \mathrm{m}^{3}\right]$, Manganese $\mathrm{Mn}^{++}$content $<0.050\left[\mathrm{~g} \mathrm{Mn}^{++} / \mathrm{m}^{3}\right]$.

The results discussed above confirm the results of the calculations of statistical parameters, carried out for a total of 14 wells and 3 piezometers (Table 3 ).

Generally it can be said that in the Kłodzko water intake area there are significant exceedances of the permissible value by the $\mathrm{Fe}^{++}$and $\mathrm{Mn}^{++}$contents in groundwater. Other water quality parameters did not exceed the admissible values.

The results of chemical analyses of water $\mathrm{pH}$, determined for the 14 wells located in the study area of water intake in Kłodzko, give evidence of water acidic $\mathrm{pH}$ (Table 1). The results of chemical determinations of water $\mathrm{pH}$ performed for the 3 piezometers occurring in the central part of intake area i.e., $\min , \max$ and the average indicate an alkaline pH (Table 2) (Fig. 2c), which may be related to the agricultural potential, the use of these areas. When the evaluations of basic statistics are made jointly on the basis of data from 14 wells and 3 piezometers, then the $\mathrm{pH}$ redox potential value of max shows alkaline $\mathrm{pH}$ (Table 3). The temperature ${ }^{\circ} \mathrm{C}$ reaches the average value approximating $8^{\circ}$ degrees, not exceeding $9.8^{\circ}$ (Table 1 ).

An analysis of the values of the coefficients $V$ of the particular quality parameters for the 14 wells shows that $\mathrm{Fe}^{++}$content, nitrate ion $\mathrm{NO}_{3}^{-}$content, ammonium ion $\mathrm{NH}_{4}^{+}$content and $\mathrm{Mn}^{++}$content vary widely (Table 1). The highest variation coefficients $V$ were obtained for $\mathrm{Fe}^{++}$content, nitrate ion $\mathrm{NO}_{3}^{-}$content and ammonium ion $\mathrm{NH}_{4}^{+}$content, indicating a great variation in these parameters, whereas $\mathrm{pH}$ potential and temperature ${ }^{\circ} \mathrm{C}$ were found to vary only slightly. The estimates of the maximum, average and minimum $\mathrm{Fe}^{++}$content and $\mathrm{Mn}^{++}$content indicate significant exceedances of the allowable values (15.11.2011). The maximum ammonium ion $\mathrm{NH}_{4}^{+}$content in the water is close to the standard value. In the case of the other analysed parameters, their maxima, minima and averages do not significantly exceed the standard values (Table 1). 
The evaluations based on the determination of the water coming from the 14 wells and the 3 new piezometers carried out in the time of 22.01.2012 -23.01 .2012 (Table 3), corroborate the results of the calculations done using the database containing only data for the 14 wells (Table 1).

The estimates of the basic statistics of the underground water quality parameters for the Kłodzko wa- ter intake area, based on the data for the 14 wells (Table 1) and jointly the 14 wells and the 3 piezometers (Table 3), indicate an extreme variation in $\mathrm{Fe}^{++}$ content, a great variation in $\mathrm{Mn}^{++}$content and very small variation in potential $\mathrm{pH}$ (Tables 1-3).

The variation coefficients $V$ calculated on the basis of the data for solely the 3 piezometers indicate a small variation in $\mathrm{Fe}^{++}$content (17\%) and an average

Table 4. Averages values of the analyzed quality parameters of underground water in the intake area in Kłodzko region (2011 year)

\begin{tabular}{|c|c|c|c|c|}
\hline $\begin{array}{c}\text { Parameter } \\
\text { analyzed }\end{array}$ & $\begin{array}{l}\text { Sample } \\
\text { size } n\end{array}$ & $\begin{array}{c}\text { Average } \\
\text { size } \bar{X} \\
\text { (with a well } \\
\text { collective leverage) }\end{array}$ & $\begin{array}{l}\text { Sample } \\
\text { size } n\end{array}$ & $\begin{array}{c}\text { Average } \\
\text { size } \bar{X} \\
\text { (without a well } \\
\text { collective leverage) }\end{array}$ \\
\hline $\begin{array}{l}\text { Oxidation-reduction } \\
\text { potential } \mathrm{pH}\end{array}$ & 14 & 6.50 & 13 & 6.49 \\
\hline $\begin{array}{l}\text { Temperature }{ }^{\circ} \mathrm{C} \\
\text { [degrees] }\end{array}$ & 14 & 7.97 & 13 & 8.00 \\
\hline $\begin{array}{l}\text { Ammonium ion } \mathrm{NH}_{4}^{+} \\
\text {content }\left[\mathrm{g} \mathrm{NH}_{4}^{+} / \mathrm{m}^{3}\right]\end{array}$ & 14 & 0.15 & 13 & 0.15 \\
\hline $\begin{array}{l}\text { Nitrate ion } \mathrm{NO}_{3}^{-} \\
\text {content }\left[\mathrm{g} \mathrm{NO}_{3}^{-} / \mathrm{m}^{3}\right]\end{array}$ & 14 & 0.88 & 13 & 0.86 \\
\hline $\begin{array}{l}\text { Phosphate ion } \mathrm{PO}_{4}^{-3} \\
\text { content }\left[\mathrm{g} \mathrm{PO}_{4}^{-3} / \mathrm{m}^{3}\right]\end{array}$ & 14 & 0.11 & 13 & 0.10 \\
\hline $\begin{array}{l}\text { Total organic coal } \mathrm{C}(\mathrm{OWO}) \\
\text { content }\left[\mathrm{gC} / \mathrm{m}^{3}\right]\end{array}$ & 14 & 1.09 & 13 & 1.07 \\
\hline \begin{tabular}{|l} 
Iron $\mathrm{Fe}^{++}$content \\
{$\left[\mathrm{gFe}^{++} / \mathrm{m}^{3}\right]$}
\end{tabular} & 14 & 0.27 & 13 & 0.28 \\
\hline $\begin{array}{l}\text { Manganese } \mathrm{Mn}^{++} \text {content } \\
{\left[\mathrm{gMn}^{++} / \mathrm{m}^{3}\right]}\end{array}$ & 14 & 0.37 & 13 & 0.38 \\
\hline
\end{tabular}

Table 5. A comparison of outlier values of quality parameters in the intake area of underground water in region of Kłodzko (2011 year)

\begin{tabular}{|c|c|c|}
\hline Parameter analyzed & $\begin{array}{l}\text { Sample } \\
\text { size } n\end{array}$ & $\begin{array}{l}\text { Outlier } \\
\text { value }\end{array}$ \\
\hline $\begin{array}{l}\text { Oxidation-reduction } \\
\text { potential } \mathrm{pH}\end{array}$ & $\begin{array}{c}14 \\
14+3\end{array}$ & $\begin{array}{c}- \\
7.41,7.39\end{array}$ \\
\hline Temperature ${ }^{\circ} \mathrm{C}$ [degrees] & 14 & 9.80 \\
\hline $\begin{array}{l}\text { Ammonium ion } \mathrm{NH}_{4}^{+} \\
\text {content }\left[\mathrm{g} \mathrm{NH}_{4}^{+} / \mathrm{m}^{3}\right]\end{array}$ & 14 & $\begin{array}{l}0.28 \\
0.47\end{array}$ \\
\hline $\begin{array}{l}\text { Nitrate ion } \mathrm{NO}_{3}^{-} \\
\text {content }\left[\mathrm{g} \mathrm{NO}_{3}^{-} / \mathrm{m}^{3}\right]\end{array}$ & 14 & 3.48 \\
\hline $\begin{array}{l}\text { Phosphate ion } \mathrm{PO}_{4}^{-3} \\
\text { content }\left[\mathrm{g} \mathrm{PO}_{4}^{-3} / \mathrm{m}^{3}\right]\end{array}$ & 14 & 0.24 \\
\hline $\begin{array}{l}\text { Total organic coal } \mathrm{C}(\mathrm{OWO}) \\
\text { content }[\mathrm{gC} / \mathrm{m} 3]\end{array}$ & 14 & $\begin{array}{l}0.71 \\
1.54\end{array}$ \\
\hline $\begin{array}{l}\text { Iron } \mathrm{Fe}^{++} \\
\text {content }\left[\mathrm{gFe}^{++} / \mathrm{m}^{3}\right]\end{array}$ & $\begin{array}{c}14 \\
14+3\end{array}$ & $\begin{array}{c}- \\
6.12,5.28,3.99\end{array}$ \\
\hline $\begin{array}{l}\text { Manganese } \mathrm{Mn}^{++} \\
\text {content }\left[\mathrm{gMn}^{++} / \mathrm{m}^{3}\right]\end{array}$ & $\begin{array}{c}14 \\
14+3\end{array}$ & 1.28 \\
\hline
\end{tabular}


variation in $\mathrm{Mn}^{++}$content $(30 \%)$ in the underground water and a very small variation in $\mathrm{pH}$ (Table 2 ). It should be noted that the min. and max. $\mathrm{Fe}^{++}$and $\mathrm{Mn}^{++}$ contents in water in the 3 piezometers considerably exceed the permissible values.

Table 4 contains the mean values of the particular quality parameters calculated with and without the data for the collecting siphon well taken into account, assuming a similar sample size [6]. It emerges from the comparison that the respective values of the parameters are identical or the differences between them are statistically insignificant (negligible). This also applies to the $\mathrm{Fe}^{++}$content and the $\mathrm{Mn}^{++}$content in the underground water (Table 4). Thus the inclusion and exclusion of the data on the water quality parameters for the collecting siphon well in/from the analysis has no effect on the estimates of the basic statistics.

For the chemical determinations (collected in the databases) of the underground water quality parameters carried out on water samples taken from the 14 wells and the 14 wells and the 3 piezometers the outliers are presented in Table 5. No outliers were found for only two water quality parameters, i.e., $\mathrm{Fe}^{++}$content and $\mathrm{pH}$ potential, analysed in the 14 wells (Table 5).

\section{DISTRIBUTION HISTOGRAMS OF UNDERGROUND WATER QUALITY PARAMETERS IN KLODZKO WATER INTAKE AREA}

The histograms of several analysed variables, i.e., water quality parameters were calculated, some of them are presented below (Figs. 3-8). There can traced diversified shapes of these histograms.

The variable range is divided into iso-width classes. To each class is associated a bar whose extension (along the vertical axis) is directly proportional to the frequency of the class, that is the percentage of samples whose value belongs to the class [15]. The minimum and maximum values are also the boundaries of the graphic representation along the horizontal axis. The vertical axis is scaled on the class with the highest frequency to be displayed.

Generally, the distribution histograms of some of the analysed parameters, plotted on the basis of the data for the 14 wells or 14 wells +3 piezometers, are strongly asymmetric (single-winged), with lower or higher frequency classes occurring (Figs. 3, 6, 7) [6]. This type of distribution characterized such parameters as $\mathrm{Fe}^{++}$content (Fig. 3), ammonium ion $\mathrm{NH}_{4}^{+}$content (Fig. 6) and nitrate ion $\mathrm{NO}_{3}^{-}$content (Fig. 7). The histograms of the other investigated parameters are bimodal, as e.g., manganese $\mathrm{Mn}^{++}$content (Fig. 4), also phosphate anion $\mathrm{PO}_{4}^{-3}$ content (Fig. 8) or multimodal for $\mathrm{pH}$ redox potential (Fig. 5). Moreover, there can be observed unimodal type of distribution as in the case of temperature ${ }^{\circ} \mathrm{C}$ and bimodal for total organic carbon (TOC) [6].

Also the shapes of the distribution histograms for the 3 quality parameters calculated using the data for the 14 wells (year 2011), including data coming from the 3 piezometers (year 2012) located in the Kłodzko water intake area, were studied [6]. The distribution histograms of $\mathrm{Fe}^{++}$content, $\mathrm{Mn}^{++}$content and $\mathrm{pH}$ potential were calculated taking into account the data for the period 15.11.2011-23.01.2012.

The $\mathrm{Fe}^{++}$content histogram is asymmetric (single-winged) and includes secondary classes of high $\mathrm{Fe}^{++}$content values, but the percentage of these classes is low (Fig. 3), in contrast to the $\mathrm{Fe}^{++}$content histogram calculated on the basis of data from the 14 wells [6]. The $\mathrm{Mn}^{++}$content histogram is bimodal (Fig. 4) while the $\mathrm{pH}$ distribution histogram is multimodal (Fig. 5).

The distribution histograms of the investigated quality parameters are characterized by a smaller or greater positive skewness coefficient $g_{1}$, except for the $\mathrm{pH}$ potential histogram, exhibiting slight negative skewness $g_{1}$ (Tables 6,7 ). The highest values of skewness $g_{1}$ were calculated for $\mathrm{Mn}^{++}$content, nitrate anion $\mathrm{NO}_{3}^{-}$con-tent and ammonium anion $\mathrm{NH}_{4}^{+}$ content, while the lowest values of $g_{1}$ were obtained for total organic carbon (TOC). From among the analysed histograms the one showing the distribution of $\mathrm{Mn}^{++}$content is the slenderest but at the same time it is characterized by the highest kurtosis coefficient $g_{2}$.

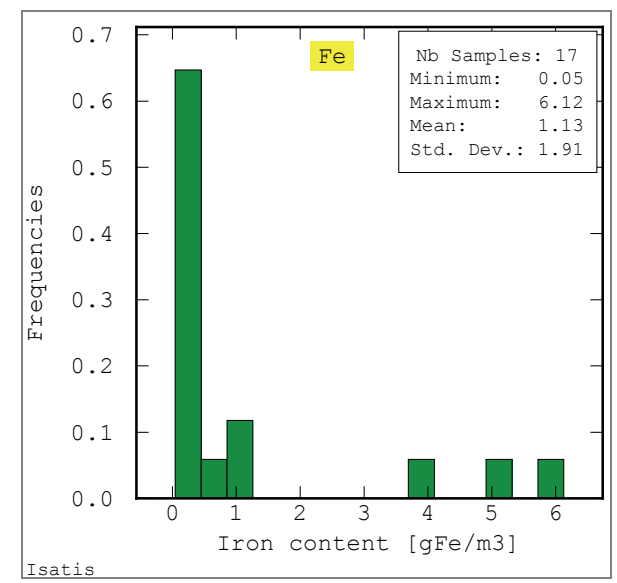

Fig. 3. Histogram of distribution of iron $\mathrm{Fe}^{++}$content $\left[\mathrm{g} \mathrm{Fe}^{++} / \mathrm{m}^{3}\right]$ in underground water for water intake area of Kłodzko (SW part of Poland); data coming from 14 wells +3 piezometers 


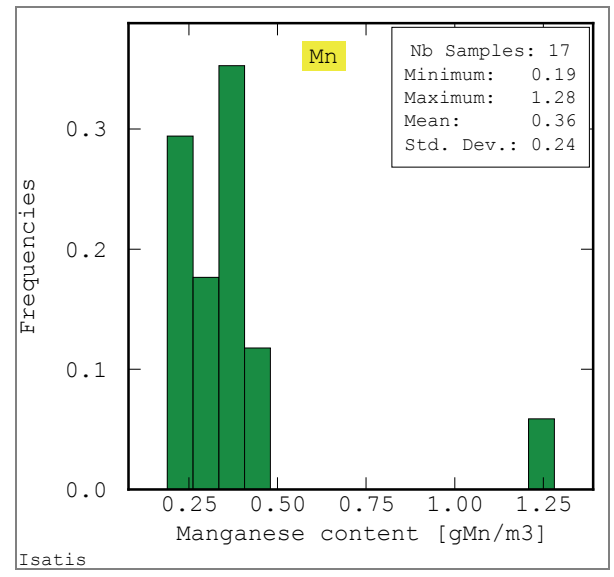

Fig. 4. Histogram of distribution of manganese $\mathrm{Mn}^{++}$content $\left[\mathrm{g} \mathrm{Mn}^{++} / \mathrm{m}^{3}\right]$ in underground water

for water intake area of Kłodzko (SW part of Poland); data coming from 14 wells +3 piezometers

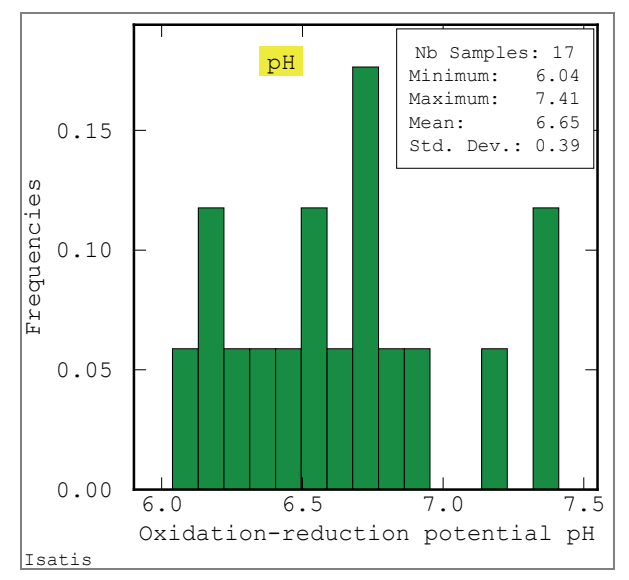

Fig. 5. Histogram of distribution of oxidation-reduction potential $\mathrm{pH}$ in underground water for water intake area of Kłodzko (SW part of Poland); data coming from 14 wells +3 piezometers

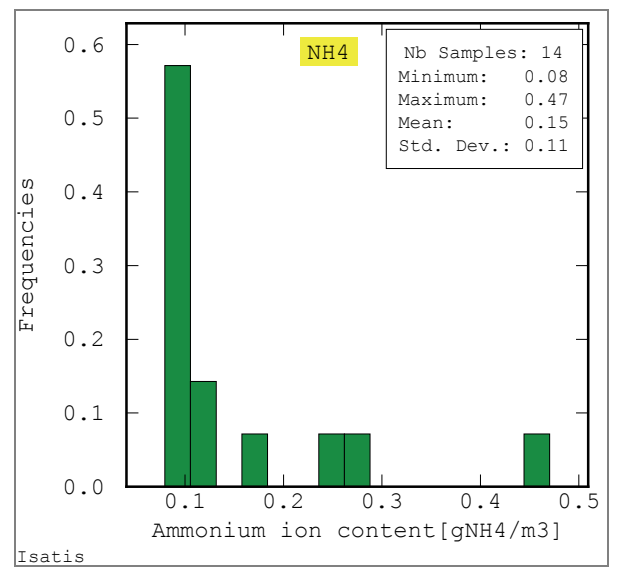

Fig. 6. Histogram of distribution of ammonium $\mathrm{NH}_{4}^{+}$ion content $\left[\mathrm{g} \mathrm{NH} \mathrm{NH}_{4}^{+} / \mathrm{m}^{3}\right]$ in underground water for water intake area of Kłodzko (SW part of Poland); data coming from 14 wells

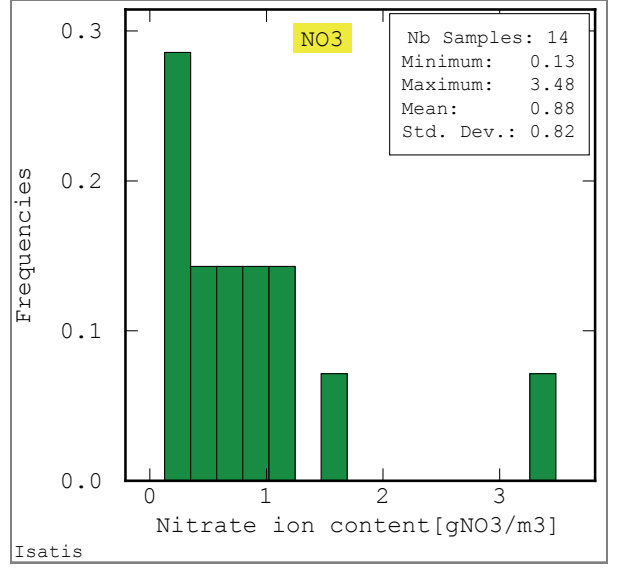

Fig. 7. Histogram of distribution of nitrate $\mathrm{NO}_{3}^{-}$ion content $\left[\mathrm{g} \mathrm{NO}_{3}^{-} / \mathrm{m}^{3}\right]$ in underground water for water intake area of Kłodzko (SW part of Poland); data coming from 14 wells

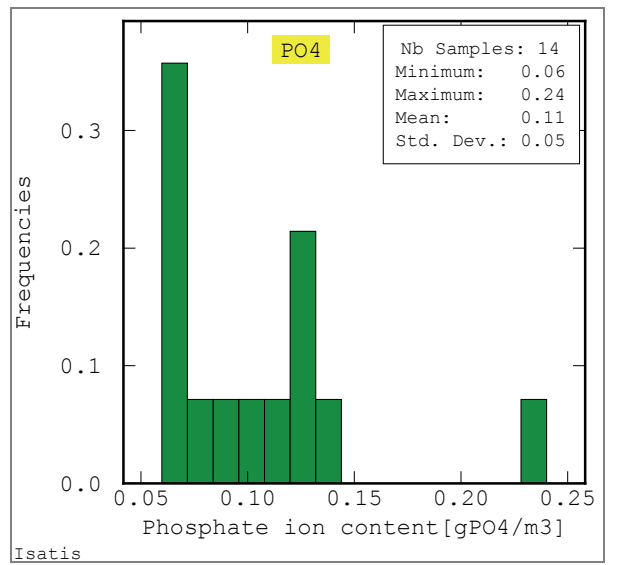

Fig. 8. Histogram of distribution of phosphate ion $\mathrm{PO}_{4}^{-}$content $\left[\mathrm{g} \mathrm{PO}_{4}^{-} / \mathrm{m}^{3}\right]$ in underground water for water intake area of Kłodzko (SW part of Poland); data coming from 14 wells

Table 6. A comparison of values of skewness $g_{1}$ and kurtosis $g_{2}$ of distributions histograms of quality parameters in the intake area of underground water in region of Kłodzko (14 wells) (year 2011)

\begin{tabular}{|c|c|c|}
\hline Parameter analyzed & Skewness $g_{1}$ & Kurtosis $g_{2}$ \\
\hline $\begin{array}{l}\text { Oxidation-reduction } \\
\text { potential } \mathrm{pH}\end{array}$ & -0.33 & 1.86 \\
\hline Temperature ${ }^{\circ} \mathrm{C}$ & 1.55 & 5.41 \\
\hline $\begin{array}{l}\text { Ammonium ion } \mathrm{NH}_{4}^{+} \\
\text {content }\left[\mathrm{g} \mathrm{NH}_{4}^{+} / \mathrm{m}^{3}\right]\end{array}$ & 1.94 & 5.84 \\
\hline $\begin{array}{l}\text { Nitrate ion } \mathrm{NO}_{3}^{-} \\
\text {content }\left[\mathrm{g} \mathrm{NO} \mathrm{NO}_{3}^{-} / \mathrm{m}^{3}\right]\end{array}$ & 2.13 & 7.37 \\
\hline $\begin{array}{l}\text { Phosphate ion } \mathrm{PO}_{4}^{-3} \\
\text { content }\left[\mathrm{g} \mathrm{PO}_{4}^{-3} / \mathrm{m}^{3}\right]\end{array}$ & 1.56 & 5.34 \\
\hline $\begin{array}{l}\text { Total organic coal } \mathrm{C}(\mathrm{OWO}) \\
\text { content }\left[\mathrm{g} \mathrm{C} / \mathrm{m}^{3}\right]\end{array}$ & 0.39 & 4.33 \\
\hline $\begin{array}{l}\text { Iron Fe } \mathrm{Fe}^{+++} \text {content } \\
{\left[\mathrm{g} \mathrm{Fe}^{++} / \mathrm{m}^{3}\right]}\end{array}$ & 1.42 & 3.58 \\
\hline $\begin{array}{l}\text { Manganese } \mathrm{Mn}^{++} \\
\text {content }\left[\mathrm{g} \mathrm{Mn}^{++} / \mathrm{m}^{3}\right]\end{array}$ & 2.87 & 10.24 \\
\hline
\end{tabular}


Table 7. A comparison of values of skewness $g_{1}$ and kurtosis $g_{2}$ of distributions histograms of quality parameters of underground water in region of Kłodzko (14 wells +3 piezometers) (year 2012)

\begin{tabular}{|l|c|c|}
\hline \multicolumn{1}{|c|}{ Parameter analyzed } & Skewness $g_{1}$ & Kurtosis $g_{2}$ \\
\hline $\mathrm{pH}$ & 0.4697 & 2.4755 \\
\hline $\begin{array}{l}\mathrm{Iron} \mathrm{Fe}^{++} \\
\text {content }\left[\mathrm{g} \mathrm{Fe}^{++} / \mathrm{m}^{3}\right]\end{array}$ & 1.7619 & 4.4271 \\
\hline $\begin{array}{l}\text { Manganese Mn } \\
\text { content }\left[\mathrm{g} \mathrm{Mn}^{++} / \mathrm{m}^{3}\right]\end{array}$ & 3.0446 & 11.8570 \\
\hline
\end{tabular}

\section{CORRELATION BETWEEN UNDERGROUND WATER QUALITY PARAMETERS IN KŁODZKO WATER INTAKE AREA}

In the next stage of the investigations the correlation $r$ between the original values of the particular underground water quality parameters, taking into account the data obtained from the chemical analyses carried out on 15.11.2011 for the 14 selected wells located in the Kłodzko water intake area, was studied [6], [10], [14].

The scatter diagram allows the plotting of a scatter plot between any pair of variables among the selected ones, that is the representation of two variables in an $X-Y$ diagram [15]. Each sample, where both variables are defined is represented by a symbol whose coordinates correspond to the values of each variable. The two variables of the pair do not play a symmetrical role. The target variable $(Y)$ is displayed along the vertical axis, whereas the horizontal axis corresponds to the conditioning variable $(X)$. The linear regression $Y / X$ was drawn in scatter plot (the regression line of the target variable $Y$ as a linear function of the conditioning variable $X$ ).

A correlation coefficient has been determined, according to the formula expressed below

$$
r=\frac{\sum_{i=1}^{1 / N} w_{i}\left[\sum_{i=1}^{N} w_{i}\left(Z_{i}-m_{z}^{w}\right)^{4}\right]}{\sigma_{z}^{w^{4}}},
$$

where

$m_{z}^{w}-$ weighted arithmetic mean,

$$
m_{z}^{w}=\frac{\sum_{i=1}^{N} w_{i} Z}{\sum_{i=1}^{N} w_{i}},
$$

$\sigma_{z}^{w^{2}}-$ weighted variance,

$$
\sigma_{z}^{w^{2}}=\frac{\sum_{i=1}^{N} w_{i}\left(Z_{i}-m_{z}^{w}\right)^{2}}{\sum_{i=1}^{N} w_{i}},
$$

$N$ - the total number of points,

$Z_{i}$ - the value of the variable at a given point,

$w_{i}$ - the weight assigned to a given point (sample),

$\sigma_{z}^{w}$ - the weighted standard deviation.

The exemplary scatter diagrams of water quality parameters, shown in Figs. 9-16, with plotted regression lines, illustrate the interdependences between the values of some of the water quality parameters for which a distinct correlation became apparent and higher coefficient values $r$ were obtained.

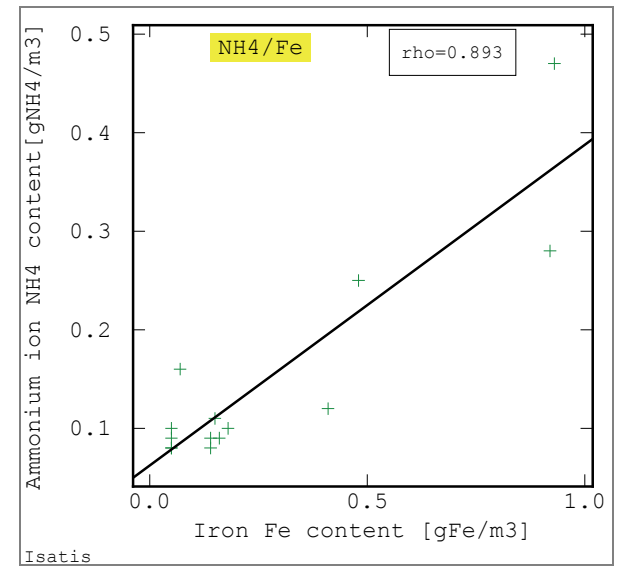

Fig. 9. Diagram correlation of $\mathrm{Fe}^{++}$iron content $\left[\mathrm{g} \mathrm{Fe}^{++} / \mathrm{m}^{3}\right]$ and $\mathrm{NH}_{4}^{+}$ammonium ion content $\left[\mathrm{g} \mathrm{NH}_{4}^{+} / \mathrm{m}^{3}\right]$ in underground water, with the marked regression line $Y / X$ in the area of water intake in the region of Kłodzko (14 wells)

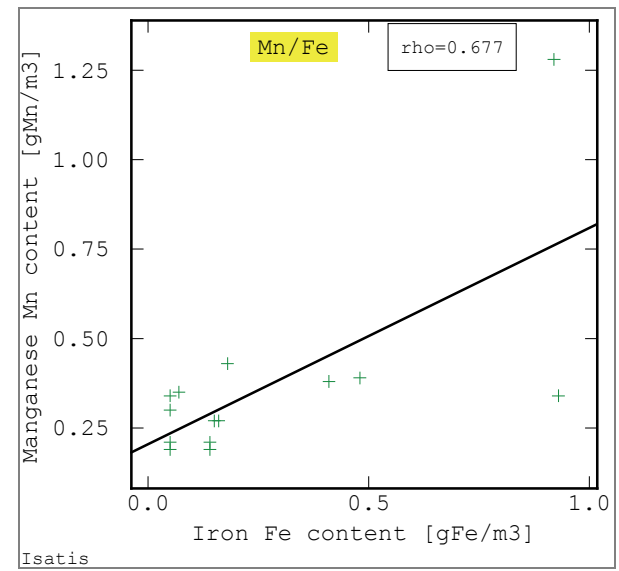

Fig. 10. Diagram correlation of iron $\mathrm{Fe}^{++}$content $\left[\mathrm{g} \mathrm{Fe}^{++} / \mathrm{m}^{3}\right]$ and manganese $\mathrm{Mn}^{++}$content $\left[\mathrm{g} \mathrm{Mn}^{++} / \mathrm{m}^{3}\right]$ in underground water, with the marked regression line $Y / X$ in the area of water intake in the region of Kłodzko (14 wells) 


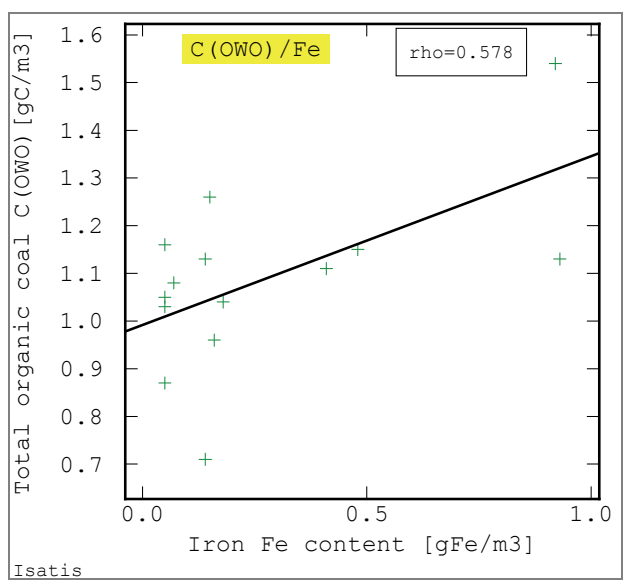

Fig. 11. Diagram correlation of iron $\mathrm{Fe}^{++}$content $\left[\mathrm{g} \mathrm{Fe}^{++} / \mathrm{m}^{3}\right]$ and total organic coal $\mathrm{C}(\mathrm{OWO})\left[\mathrm{g} \mathrm{C} / \mathrm{m}^{3}\right]$ in underground water, with the marked regression line $Y / X$ in the area of water intake in the region of Kłodzko (14 wells)

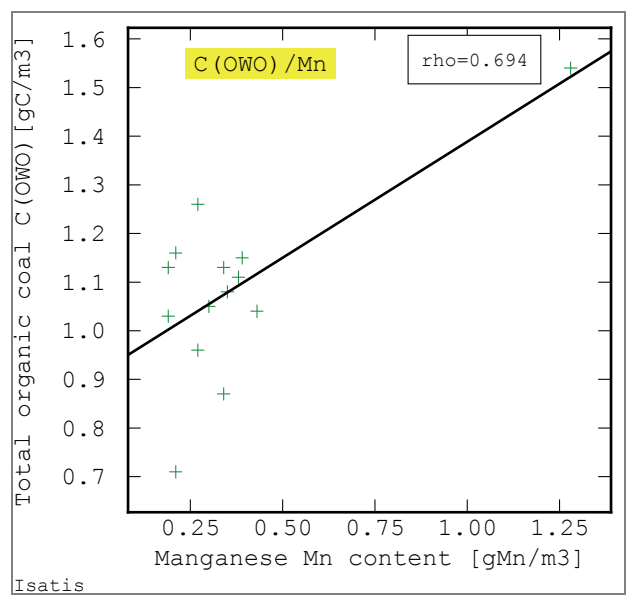

Fig. 12. Diagram correlation of manganese $\mathrm{Mn}^{++}$content $\left[\mathrm{g} \mathrm{Mn}^{++} / \mathrm{m}^{3}\right]$ and total organic coal C (OWO) $\left[\mathrm{gC} / \mathrm{m}^{3}\right]$ in underground water, with the marked regression line $Y / X$ in the area of water intake in the region of Kłodzko (14 wells)

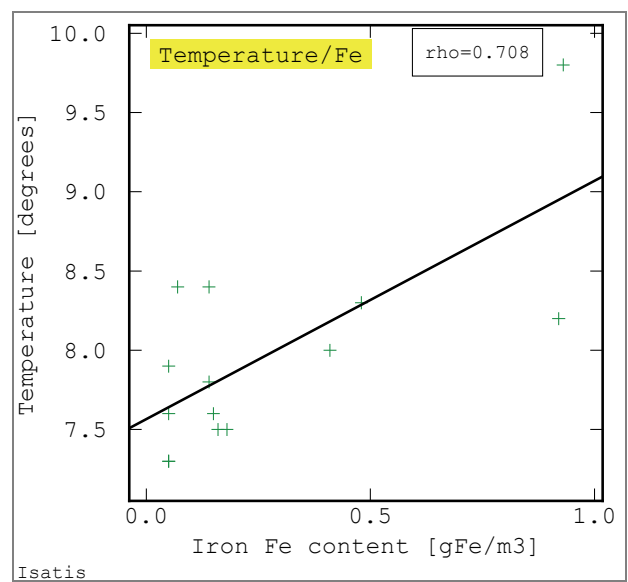

Fig. 13. Diagram correlation of iron $\mathrm{Fe}^{++}$content $\left[\mathrm{g} \mathrm{Fe}^{++} / \mathrm{m}^{3}\right]$ and temperature ${ }^{\circ} \mathrm{C}$ [degrees] in underground water, with the marked regression line $Y / X$ in the area of water intake in the region of Kłodzko (14 wells)

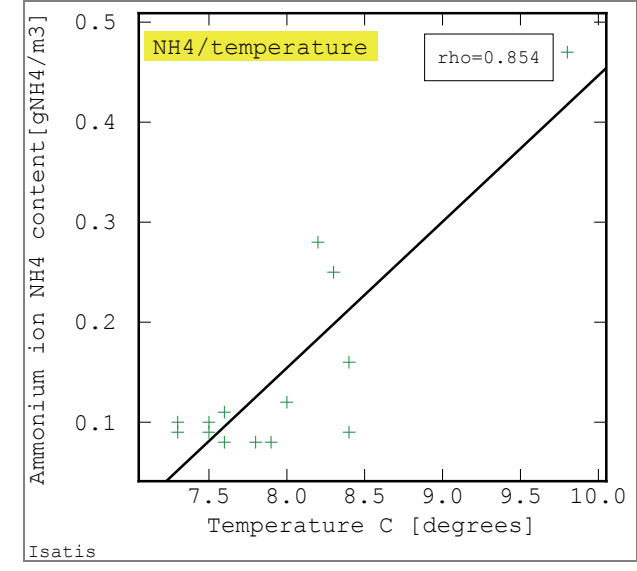

Fig. 14. Diagram correlation of temperature ${ }^{\circ} \mathrm{C}$ [degrees] and ammonium ion $\mathrm{NH}_{4}^{+}$content $\left[\mathrm{g} \mathrm{NH}_{4}^{+} / \mathrm{m}^{3}\right]$ in underground water, with the marked regression line $Y / X$ in the area of water intake in the region of Kłodzko (14 wells)

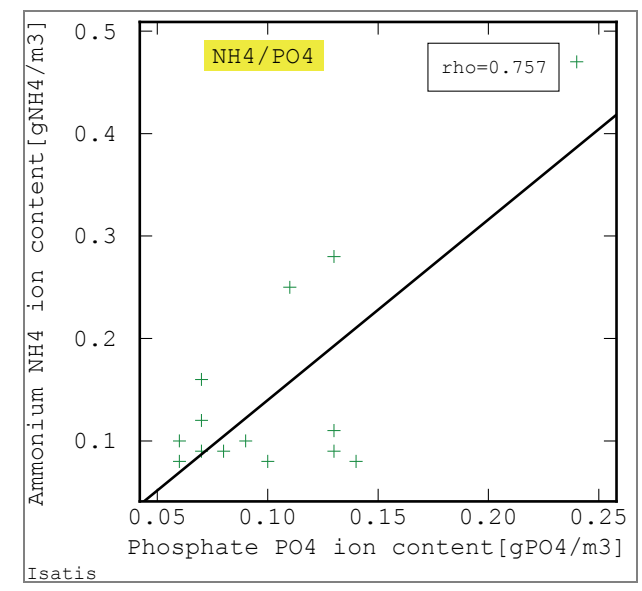

Fig. 15. Diagram correlation of phosphate ion $\mathrm{PO}_{4}^{-}$content [g $\left.\mathrm{PO}_{4}^{-} / \mathrm{m}^{3}\right]$ and ammonium ion $\mathrm{NH}_{4}^{+}$content $\left[\mathrm{g} \mathrm{NH}_{4}^{+} / \mathrm{m}^{3}\right]$ in underground water, with the marked regression line $Y / X$ in the area of water intake in the region of Kłodzko (14 wells)

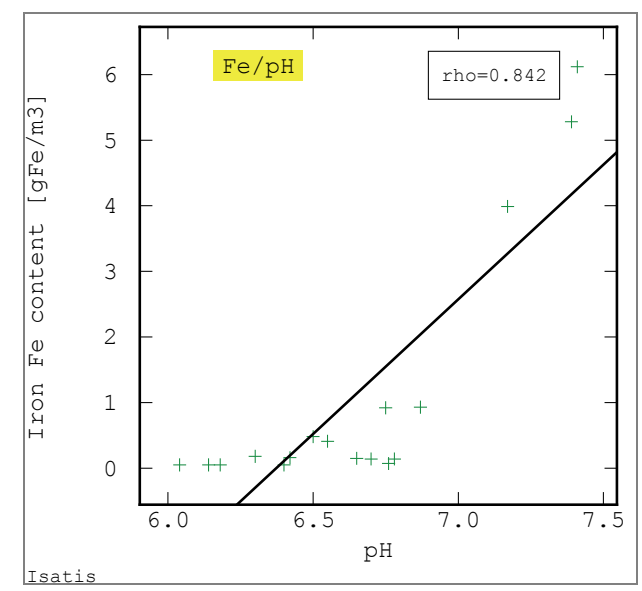

Fig. 16. Diagram correlation of iron $\mathrm{Fe}^{++}$content $\left[\mathrm{gFe}^{++} / \mathrm{m}^{3}\right]$ and potential $\mathrm{pH}$ in underground water, with the marked regression line $Y / X$ in the area of water intake in the region of Kłodzko (14 wells) 
The highest positive correlation coefficients $r$ values were found between respectively: $\mathrm{Fe}^{++}$content and ammonium ion $\mathrm{NH}_{4}^{+}$content $(r=0.89)$ (Fig. 9), $\mathrm{Fe}^{++}$content and $\mathrm{Mn}^{++}$content $(r=0.68)$ (Fig. 10), $\mathrm{Fe}^{++}$content and total organic carbon $\mathrm{C}(r=0.69)$ (Fig. 11), $\mathrm{Mn}^{++}$content and total organic carbon $\mathrm{C}$ $(r=0.69)$ (Fig. 12), $\mathrm{Fe}^{++}$content and temperature ${ }^{\circ} \mathrm{C}$ $(r=0.71)$ (Fig. 13), ion $\mathrm{NH}_{4}^{+}$content and temperature ${ }^{\circ} \mathrm{C}(r=0.85)$ (Fig. 14), ion $\mathrm{NH}_{4}^{+}$content and phosphate $\mathrm{PO}_{4}^{-3}$ ion content $(r=0.76)$ (Fig. 15).

It can be noticed that very high correlation coefficient value $r$ was obtained for the correlation between $\mathrm{Fe}^{++}$content and $\mathrm{pH}$ for 14 wells and 3 piezometers $r=0.842$ (Fig. 16). High values of $\mathrm{Fe}^{++}$content and $\mathrm{pH}$ were observed in the same places in the middle of the study area, showing a character of underground water environment (Figs. 2a, 2c).

A slightly weaker, but distinct, positive correlation coefficients $r$ values were found between respectively: $\mathrm{Fe}^{++}$content and phosphate anion $\mathrm{PO}_{4}^{-3}$ content $(r=0.60)$, anion $\mathrm{PO}_{4}^{-3}$ content and temperature ${ }^{\circ} \mathrm{C}$ $(r=0.61)$, temperature ${ }^{\circ} \mathrm{C}$ and $\mathrm{pH}$ redox potential $(r=$ $0.64)[6]$.

The observed relationships between individual quality parameters, first of all $\mathrm{Fe}^{++}$content, $\mathrm{NH}_{4}^{+}$content and $\mathrm{PO}_{4}^{-3}$ content seem to prove a similar source of underground water pollution connected first of all with farming, improper fertilization of agricultural land in this area.

\section{ANALYSIS OF DIRECTIONAL SEMIVARIOGRAMS OF UNDERGROUND WATER QUALITY PARAMETERS IN KŁODZKO WATER INTAKE AREA}

In order to estimate the spatial variation of underground water quality parameters geostatistical methods were used, such as the variogram function and then estimation technique - ordinary kriging [1], [3], [5], [15]-[17].

Empirical variogram describes correlation of the studied variables, i.e., underground water quality parameter values over an area considered (in 2D, 3D). In practice most often applied empirical measure of variability is semivariogram, determined and represented by the following formula [17]:

$$
\gamma^{*}(h)=\frac{1}{2 n_{h}} \sum_{i=1}^{n_{h}}\left[z\left(x_{i}+h\right)-z\left(x_{i}\right)\right]^{2}
$$

where $z\left(x_{i}+h\right), z\left(x_{i}\right)$ - values of the regionalized variable under study at points $x_{i}$ and $x_{i}+h$, and therefore spaced by distance $h ; n_{h}$ - number of pairs $\left(x_{i}, x_{i}+h\right)$ of a given regionalized variable at points spaced by distance $h$, used in the calculation of semivariogram function $\gamma^{*}(h) ; \gamma^{*}(h)$ - values of semivariogram function.

Empirical variograms courses describe the nature and degree of variation of the regionalised variables under consideration, i.e., underground water quality parameter values. A graph of semivariogram function $\gamma^{*}(h)$ is named the empirical or experimental semivariogram.

Various analytical functions, named "geostatistical models" can be used for the approximation of empirical semivariogram courses [1], [3], [5], [15], [16]. Theoretical semivariogram is a characteristic of topoprobabilistic model which is usually referred to as a semivariogram, for short. In geostatistics, the representation of a regionalized variable by a random function is a topoprobabilistic model (any approach using the notation of probability to describe a phenomenon varying in space).

A semivariogram is a measure traditionally defined as half of the quadratic mean of the difference between two values of a measurable characteristic (the regionalized variable), separated by approximately distance $h$ (vector $h$ ). A variogram is equal to twice the semivariogram. Half of the variogram of order 2 is the semivariogram. Variogram is sometimes used as a synonym for semivariogram.

A spherical model is a commonly applied model of variogram of the following shape: almost linear rising, increasing up to a certain distance, but stabilizing [17]. This model is determined by real (actual) range of influence of variogram $a$, a positive value of part of sill variance $C$, and nugget variance $C_{0}$

$$
\begin{aligned}
& \begin{aligned}
\gamma(h)=C \operatorname{Sph}\left(\frac{h}{a}\right) & =C\left[1.5 \frac{h}{a}-0.5\left(\frac{h}{a}\right)^{3}\right]+C_{0} & & \text { if } \quad h \leq a \\
& =C+C_{0} & & \text { if } \quad h \geq a
\end{aligned} \\
& \gamma(h)=0 \text { if } h=0 .
\end{aligned}
$$

Different geostatistical parameters of fitted theoretical models such as total sill variance $C$, nugget effect $C_{0}$ and range of influence $a$ have been determined.

The $C_{0}$ nugget effect is a visible discontinuity in the course of empirical semivariogram (at the starting point of the graph $\gamma(h)$ [1], [3], [5], [15]-[17]. The effect $C_{0}$ is 
the variation process' random factor. This effect is caused by measurement errors or micro-nest structures smaller than the sampling distance, or by both causes. At the beginning of the semivariogram graph the value of function $\gamma(h)$ is always 0 , however, in the absence of $C_{0}$ effect it aims to a positive value of $C_{0}$, significantly greater than $0 . C_{0}$ effect indicates the presence of the effect on the occurrence of local variation, which means rapid fluctuation in the quality parameters under study.

The total sill variance $C$ is the upper limit of the adopted variogram model, possible to achieve at long distances, for the large arguments transitive variogram type [1], [3], [5], [15]-[17]. The $C_{0}$ effect and partial variance $C^{\prime}$ taken together give the total sill variance $C$ that represents the overall variation of the analyzed variable.

The range of influence $a$ for a spherical model variogram is the distance at which the model reaches its maximum - the sill variance $C$ [1], [3], [5], [15] -[17]. The range $a$ means that up to this distance there is a measurable correlation with adjacent sample values.

As part of the structural analysis the courses of the directional semivariograms (D-90) of 8 underground water quality parameters were examined downwards the wells depth in the Kłodzko water intake area (Figs. 17-22). The semivariograms had been calculated on the basis of the results of the chemical analyses of water samples taken from the selected 14 wells, including the siphon well, located in the water intake area, carried out on 15.11.2011 [6]. The shapes of the directional semivariograms determined for the 14 wells selected from among the 22 wells located in the water intake area were studied [6], [10], [13], [14]. The database established for the 14 wells in November 2011 was expanded to include additionally the results of the chemical analyses of the water samples taken from the 3 piezometers in the Kłodzko water intake area carried out in January 2012 [6].

Periodic variation can be discerned in the three semivariograms: of $\mathrm{Fe}^{++}$content and $\mathrm{Mn}^{++}$content [6] and also ammonium ion $\mathrm{NH}_{4}^{+}$content (Fig. 20). A less distinct regularity, i.e., merely a tendency towards periodic variation, can be discerned in the semivariograms of nitrate anion $\mathrm{NO}_{3}^{-}$content (Fig. 21), phosphate anion $\mathrm{PO}_{4}^{-3}$ content (Fig. 22) and total organic carbon $\mathrm{C}$ (TOC) [6]. A strong growing variation trend is evident in the directional semivariogram of $\mathrm{pH}$ potential (Fig. 19a), indicating distinct directional changes in this parameter along the depth of the wells. A similar tendency, but weaker, is visible in the directional semivariogram of temperature ${ }^{\circ} \mathrm{C}[6]$.
Also the directional semivariograms of three underground water quality parameters, i.e., $\mathrm{Fe}^{++}$content (Fig. 17), $\mathrm{Mn}^{++}$content (Fig. 18) and $\mathrm{pH}$ (Fig. 19b), determined on the basis of samples coming from the 14 wells including the 3 piezometers in the period of 15.11.11-23.01.12 were analysed. However, no distinct regularities in the variation of the parameters along the wells depth can be discerned in the semivariograms. A very strong short-periodic variation in function $\gamma(h)$ is observed. The most distinct changes of this kind are observed in the semivariogram of $\mathrm{Mn}^{++}$content (Fig. 18).

Over the longer period (years 1977-2012) an increasing trend in the variation of $\mathrm{Fe}^{++}$content and $\mathrm{Mn}^{++}$content in the underground water in the Kłodzko water intake area clearly emerges. It is gentler for $\mathrm{Fe}^{++}$ and steeper for $\mathrm{Mn}^{++}$[9], [10], [13], [14].

Generally, it is supposed that the quality of both the network water and the treated water can be the resultant of the quality of underground water in the Kłodzko water intake area, i.e., of the changes in $\mathrm{Fe}^{++}$and $\mathrm{Mn}^{++}$ content taking place in the years 1977-2012 [11], [12]. In the analysed shorter period (2007-2011) towards 2011 a clearly downward trend in $\mathrm{Fe}^{++}$content in Kłodzko water supply system, accompanied by a tendency towards periodic variation, became clearly apparent [11], [12]. The $\mathrm{Mn}^{++}$content in the network water was characterized by an opposite behaviour, showing an upward trend in its variation towards 2011.

Tables 8,9 show the values of the geostatistical parameters of the theoretical models adopted to approximate the courses of empirical semivariograms of the water quality parameters.

The directional semivariograms of the quality parameters of the water coming from the 14 wells were approximated with a single spherical model and in three cases with a composite model being a combination of respectively two spherical models and the nugget effect, a spherical model and the nugget effect or a spherical model, cubic model and the nugget effect (Table 8).

The very short influence ranges $a$ of the semivariograms of $\mathrm{Fe}^{++}$content, $\mathrm{Mn}^{++}$content [6] and ammonium ion $\mathrm{NH}_{4}^{+}$content (Fig. 20) are conspicuous. Longer ranges $a$ are observed in the semivariograms of nitrate ion $\mathrm{NO}_{3}^{-}$content (Fig. 21), total organic carbon $\mathrm{C}$ and temperature ${ }^{\circ} \mathrm{C}$ (Table 8) [6]. A particularly long range of influence $a$ is visible in the $\mathrm{pH}$ semivariogram (Fig. 19a). No nugget effect $C_{0}$ was found in the $\mathrm{Fe}^{++}, \mathrm{Mn}^{++}$[6], $\mathrm{NH}_{4}^{+}, \mathrm{NO}_{3}^{-}$(Figs. 20-21) and temperature ${ }^{\circ} \mathrm{C}$ semivariograms [6]. The $\mathrm{C}_{0}$ effect occurred in the semivariograms of water $\mathrm{pH}$ (Fig. 19a), anion 
$\mathrm{PO}_{4}^{-3}$ content (Fig. 22) and total organic carbon $\mathrm{C}$ [6], which is evidence of a marked variation in the values of these parameters along the depth of the wells.

The directional semivariograms of the three quality parameters: $\mathrm{Fe}^{++}$content (Fig. 17 ), $\mathrm{Mn}^{++}$content (Fig. 18) and $\mathrm{pH}$ (Fig. 19b), determined on samples from the 14 wells and the 3 piezometers over the very short test period of 15.11.11-23.01.12 were analysed. The semivariograms were approximated using a composite model consisting of the two spherical models and the nugget effect (Table 9).
There can noticed the relatively long ranges of influence $a$ of semivariograms of $\mathrm{Fe}^{++}$and $\mathrm{Mn}^{++}$ content in groundwater (Table 9), in comparison with the results obtained, taking into account the data related to the 14 wells, i.e., showing extremely short ranges $a$ (Table 8). However, in these conditions resulting in very short ranges $a$ of $\mathrm{pH}$ semivariograms (14 wells +3 piezometers) (Table 9), compared to very long ranges $a$ of $\mathrm{pH}$ semivariograms calculated using data deriving from 14 wells (Table 8).

Table 8. Comparison of values of geostatistical models of directional semivariograms D-90 of quality parameters of underground water in area of water intake in the region of Kłodzko; (14 wells) (year 2011)

\begin{tabular}{|c|c|c|c|c|c|}
\hline $\begin{array}{l}\text { Parameter } \\
\text { analyzed }\end{array}$ & $\begin{array}{l}\text { Nugget } \\
\text { effect } C_{0} \\
{\left[\mathrm{~g} / \mathrm{m}^{3}\right]^{2}}\end{array}$ & $\begin{array}{c}\text { Partial sill } \\
\text { variance } C^{\prime} \\
{\left[\mathrm{g} / \mathrm{m}^{3}\right]^{2}}\end{array}$ & $\begin{array}{c}\text { Total } \\
\text { sill } \\
\text { variance } C \\
{\left[\mathrm{~g} / \mathrm{m}^{3}\right]^{2}}\end{array}$ & $\begin{array}{l}\text { Range of } \\
\text { influence } a \\
\text { [m] }\end{array}$ & $\begin{array}{c}\text { Basic } \\
\text { model } \\
\text { structures }\end{array}$ \\
\hline $\begin{array}{l}\text { Iron } \mathrm{Fe}^{++} \text {content } \\
{\left[\mathrm{g} \mathrm{Fe}^{++} / \mathrm{m}^{3}\right]}\end{array}$ & - & - & 0.13867 & 0.13 & spherical \\
\hline $\begin{array}{l}\text { Manganese } \mathrm{Mn}^{++} \text {content } \\
{\left[\mathrm{g} \mathrm{Mn}^{++} / \mathrm{m}^{3}\right]}\end{array}$ & - & - & 0.10875859 & 0.14 & spherical \\
\hline $\begin{array}{l}\text { Ammonium ion } \mathrm{NH}_{4}^{+} \text {content } \\
{\left[\mathrm{g} \mathrm{NH} / \mathrm{m}^{3}\right]}\end{array}$ & - & $\begin{array}{l}0.015885 \\
0.002276\end{array}$ & 0.018161 & $\begin{array}{l}0.13 \\
0.13\end{array}$ & $\begin{array}{l}\text { spherical } \\
\text { spherical }\end{array}$ \\
\hline $\begin{array}{l}\text { Nitrate ion } \mathrm{NO}_{3}^{-} \text {content } \\
{\left[\mathrm{g} \mathrm{NO}_{3}^{-} / \mathrm{m}^{3}\right]}\end{array}$ & - & $\begin{array}{l}0.491955 \\
0.545665\end{array}$ & 1.037620 & $\begin{array}{l}0.54 \\
0.74\end{array}$ & $\begin{array}{l}\text { spherical } \\
\text { spherical }\end{array}$ \\
\hline $\begin{array}{l}\text { Phosphate ion content } \mathrm{PO}_{4}^{-3} \\
{\left[\mathrm{~g} \mathrm{PO}_{4}^{-3} / \mathrm{m}^{3}\right]}\end{array}$ & 0.001086 & 0.002002 & 0.003088 & 0.35 & $\begin{array}{c}\text { nugget effect } \\
\text { spherical }\end{array}$ \\
\hline $\begin{array}{l}\text { Total organic coal } \mathrm{C}(\mathrm{OWO}) \text { content } \mathrm{C} \\
{\left[\mathrm{g} \mathrm{C} / \mathrm{m}^{3}\right]}\end{array}$ & 0.025273 & 0.020672 & 0.045945 & 0.44 & $\begin{array}{l}\text { nugget effect } \\
\text { spherical }\end{array}$ \\
\hline Oxidation-reduction potential $\mathrm{pH}$ & 0.025830 & $\begin{array}{l}5.330109 \\
0.212198\end{array}$ & 5.568137 & $\begin{array}{l}189.52 \\
227.48\end{array}$ & $\begin{array}{c}\text { nugget effect } \\
\text { cubic, } \\
\text { spherical }\end{array}$ \\
\hline $\begin{array}{l}\text { Temperature }\left[{ }^{\circ} \mathrm{C}\right] \\
{[\text { degrees }]}\end{array}$ & - & $\begin{array}{l}0.103170 \\
0.468727\end{array}$ & 0.57187 & $\begin{array}{l}0.56 \\
1.48\end{array}$ & $\begin{array}{l}\text { spherical } \\
\text { spherical }\end{array}$ \\
\hline
\end{tabular}

Table 9. Comparison of values of geostatistical models of directional semivariograms D-90 of quality parameters of underground water in area of water intake in the region of Kłodzko; (14 wells +3 piezometers) (year 2012)

\begin{tabular}{|l|c|c|c|c|c|}
\hline \multicolumn{1}{|c|}{$\begin{array}{c}\text { Parameter } \\
\text { analyzed }\end{array}$} & $\begin{array}{c}\text { Nugget } \\
\text { effect } C_{0} \\
{\left[\mathrm{~g} / \mathrm{m}^{3}\right]^{2}}\end{array}$ & $\begin{array}{c}\text { Partial } \\
\text { sill } \\
\text { variance } C^{\prime} \\
{\left[\mathrm{g} / \mathrm{m}^{3}\right]^{2}}\end{array}$ & $\begin{array}{c}\text { Total } \\
\text { sill } \\
\text { variance } C \\
{\left[\mathrm{~g} / \mathrm{m}^{3}\right]^{2}}\end{array}$ & $\begin{array}{c}\text { Range of } \\
\text { influence } a \\
{[\mathrm{~m}]}\end{array}$ & $\begin{array}{c}\text { Basic } \\
\text { model } \\
\text { structures }\end{array}$ \\
\hline $\begin{array}{l}\mathrm{Iron} \mathrm{Fe}^{++} \text {content } \\
{\left[\mathrm{g} \mathrm{Fe} / \mathrm{m}^{3}\right]}\end{array}$ & 0.36400 & $\begin{array}{c}1.6380 \\
1.6380\end{array}$ & 3.64000 & $\begin{array}{c}0.22 \\
0.88\end{array}$ & $\begin{array}{c}\text { nugget effect } \\
\text { spherical } \\
\text { spherical }\end{array}$ \\
\hline $\begin{array}{l}\text { Manganese Mn } \\
{\left[\mathrm{g} \mathrm{Mn}{ }^{++} / \mathrm{m}^{3}\right]}\end{array}$ & 0.005932 & 0.029389 & 0.095201 & 0.43 & $\begin{array}{c}\text { nugget effect } \\
\text { spherical } \\
\text { spherical }\end{array}$ \\
\hline $\begin{array}{l}\text { Oxidation-reduction } \\
\text { potential } \mathrm{pH}\end{array}$ & 0.015346 & $\begin{array}{c}0.069059 \\
0.062716\end{array}$ & 0.131775 & 0.22 & $\begin{array}{c}\text { nugget effect } \\
\text { spherical } \\
\text { spherical }\end{array}$ \\
\hline
\end{tabular}




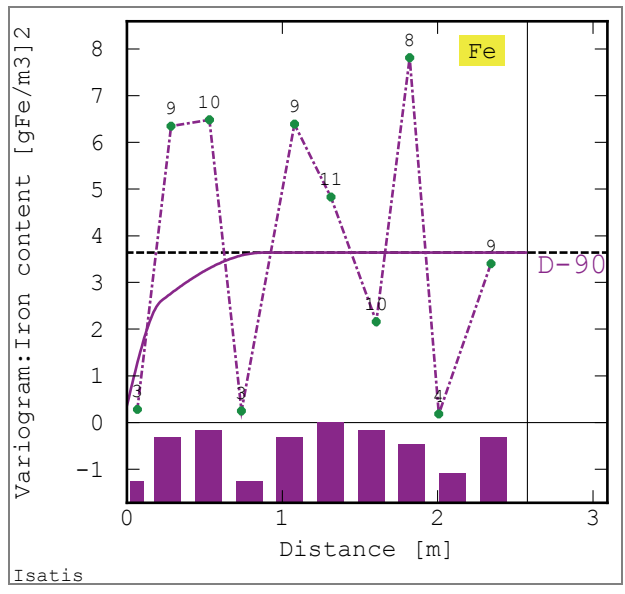

Fig. 17. Directional semivariogram (D-90) of iron $\mathrm{Fe}^{++}$content $\left[\mathrm{g} \mathrm{Fe}^{++} / \mathrm{m}^{3}\right]^{2}$ in underground water in Kłodzko intake area; 14 wells +3 piezometers

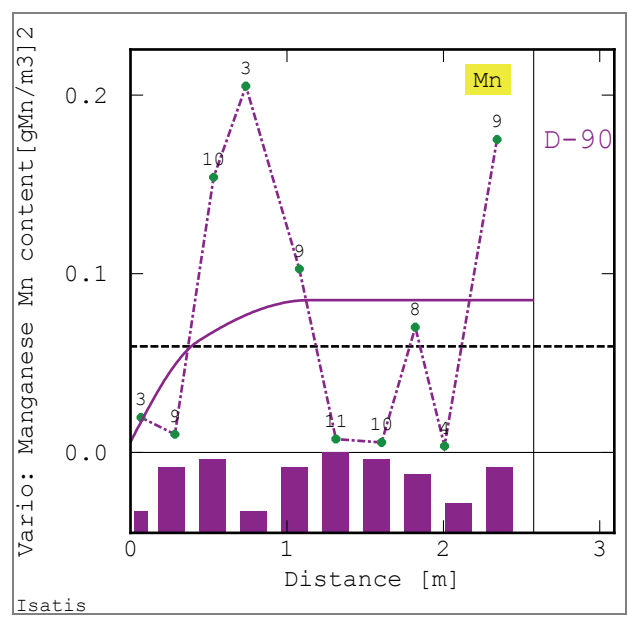

Fig. 18. Directional semivariogram (D-90) of manganese Mn content $\left[\mathrm{g} \mathrm{Mn}^{++} / \mathrm{m}^{3}\right]^{2}$ in underground water in Kłodzko intake area; 14 wells +3 piezometers

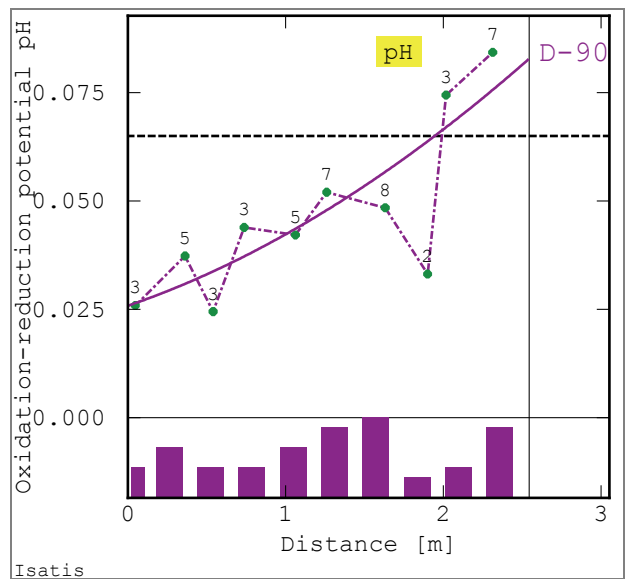

Fig. 19a. Directional semivariogram (D-90) of oxidation-reduction potential $\mathrm{pH}$ in underground water in Kłodzko intake area; 14 wells

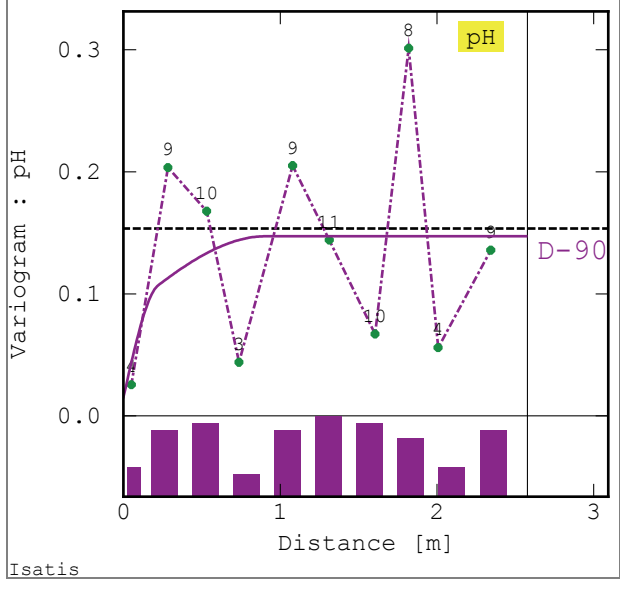

Fig. 19b. Directional semivariogram (D-90) of oxidation-reduction potential $\mathrm{pH}$ in underground water in Kłodzko intake area; 14 wells +3 piezometers

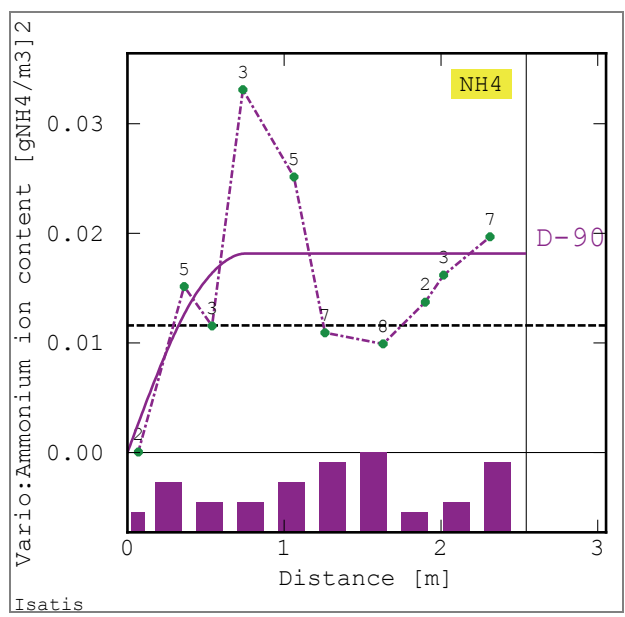

Fig. 20. Directional semivariogram (D-90) of ammonium ion $\mathrm{NH}_{4}^{+}$content $\left[\mathrm{g} \mathrm{NH}_{4}^{+} / \mathrm{m}^{3}\right]^{2}$ in underground water in Kłodzko intake area; 14 wells

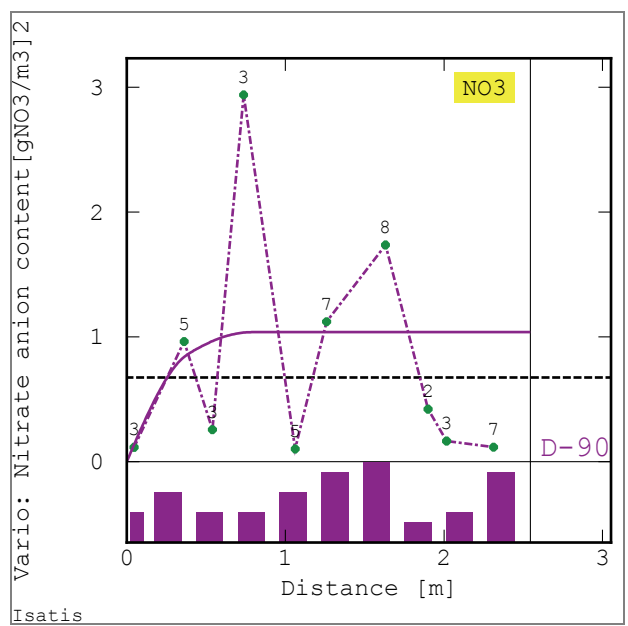

Fig. 21. Directional semivariogram (D-90) of nitrate ion $\mathrm{NO}_{3}^{-}$content $\left[\mathrm{g} \mathrm{NO}_{3}^{-} / \mathrm{m}^{3}\right]^{2}$ in underground water in Kłodzko intake area; 14 wells 


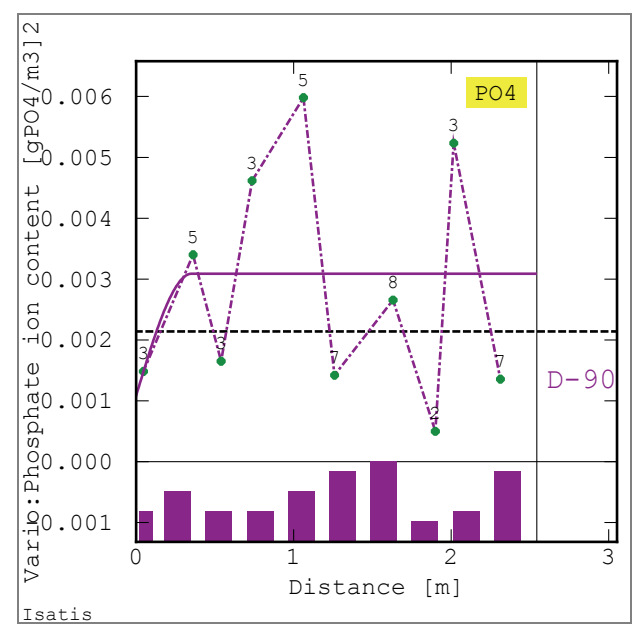

Fig. 22. Directional semivariogram (D-90) of phosphate anion $\mathrm{PO}_{4}^{-3}$ content $\left[\mathrm{g} \mathrm{PO}_{4}^{-3} / \mathrm{m}^{3}\right]^{2}$ in underground water in Kłodzko intake area; 14 wells

\section{RESULTS OF ESTIMATION OF UNDERGROUND WATER QUALITY PARAMETERS IN KLODZKO WATER INTAKE AREA USING ORDINARY KRIGING TECHNIQUE}

Estimated averages $Z^{*}$ and standard deviation of estimation $\sigma_{k}$ in the block centres of a 3D grid covering the Kłodzko water intake area were estimated using ordinary (block) kriging [1], [3], [5], [15], [16].

In the estimation procedure the ordinary kriging was used, which serves to estimate the average $Z^{*}$ in a point location (ordinary point kriging) or in the centre of a block (ordinary block kriging) [1], [3], [5], [15], [16]. This technique allows us to estimate the point or block average in a node of the elementary square or rectangular grid (block centre) as the weighted average $Z^{*}$, calculated on the basis of values measured in its local neighbourhood, i.e., in the sample search area (moving neighbourhood), for the centre of an ellipse or circle placed in the node within the block or of all available values occurring in the study area (unique neighbourhood). At the same time, with each estimated average $Z^{*}$ (kriging estimate), the standard (kriging) estimation deviation $\sigma_{k}$ or kriging variance $\sigma_{k}^{2}$ is calculated.

Weighted (moving) average $Z^{*}$ is estimated using the following formula

$$
Z_{k}^{*}=\sum_{i=1}^{n} w_{i k} z_{i}
$$

where $z_{i}$ - analysed parameter, i.e., underground quality parameter, at point $i$, for $i=1, \ldots, n$; kriging weighting factor (weight) assigned to sample $i$.

With the so called kriging system of equations (estimations) [1], [3], [5], [15], [16] it becomes possible to determine the weighting factors $w_{i k}$, assigned to data sampled within an estimated area and in its vicinity. Then they allow us to calculate the average error, called kriging error, the variance of which is given by

$$
\sigma_{k}^{2}=\Sigma w_{i k} \bar{\gamma}\left(S_{i}, A\right)+\lambda-\bar{\gamma}(A, A)
$$

where $w_{i k}$ - kriging weighting factor (weight) assigned to sample $i ; \bar{\gamma}(A, A)$ - average of the variogram function between any two points in block $A ; \bar{\gamma}\left(S_{i}, A\right)-$ average of the variogram function between sampled values $S_{i}$ and points in block $A, \lambda$ - Lagrange multiplier.

Kriging variance $\sigma_{k}^{2}$ depends on the sample positions relative to the location to be estimated, and the parameters of the adopted empirical variogram theoretical model.

Kriging calculations were made taking into account the unique "neighbourhood". This means that all data from an analysed area are taken into account when estimating the estimated averages $Z^{*}$ in each elementary block centre. The dimensions of this grid were $58 \times 46 \times 108$ along the $X$-axis, the $Y$-axis and the $Z$-axis, respectively (which corresponded to the wells depth). The respective total number of grid nodes was 291104. The mesh of assumed grid amounted to the dimensions of $0.0001 \mathrm{~m}$ $\times 0.00025 \mathrm{~m} \times 0.1 \mathrm{~m}$.

All results of the conducted estimation of the underground water quality parameters are presented in the same Tables $10-11$, in order to compare the results related to data coming from the 14 wells (year 2011) and jointly from the 14 wells and 3 piezometers (years 20112012), and moreover the data are connected with the period of the years of 1977-2011 [6], [10], [13].

The highest coefficients of the variation coefficients $V$ of estimated averages $Z^{*}$ were obtained for $\mathrm{Fe}^{++}$content and nitrate anion $\mathrm{NO}_{3}^{-}$content, followed by ammonium anion $\mathrm{NH}_{4}^{+}$content (Table 10). In the case of the other parameters, coefficients $V$ were low, reaching the lowest values for temperature ${ }^{\circ} \mathrm{C}$ and $\mathrm{pH}$.

The highest average values $(\bar{X})$ of averages $Z^{*}$ of iron $\mathrm{Fe}^{++}$content (max value of $Z^{*}$ and average $\bar{X}$ of $Z^{*}$ ) were obtained if basic statistics had been taken in the calculations, including additional data deriving from 3 piezometers (a total of 14 wells and 
Table 10. Global statistics of estimated averages $Z^{*}$ of quality parameters of underground water; results of ordinary block kriging (year $2011^{*}$; years $2011-2012^{* *}$; years $1977-2011^{* * *}$ )

\begin{tabular}{|c|c|c|c|c|c|c|}
\hline $\begin{array}{l}\text { Parameter } \\
\text { analyzed }\end{array}$ & $\begin{array}{c}\text { Number } \\
\text { of grid nodes } n\end{array}$ & $\begin{array}{c}\text { Minimal } \\
\text { value } X_{\min } \\
{\left[\mathrm{g} / \mathrm{m}^{3}\right]}\end{array}$ & $\begin{array}{c}\text { Maximal } \\
\text { value } X_{\max } \\
{\left[\mathrm{g} / \mathrm{m}^{3}\right]}\end{array}$ & $\begin{array}{c}\text { Average } \\
\text { value } \bar{X} \\
{\left[\mathrm{~g} / \mathrm{m}^{3}\right]}\end{array}$ & $\begin{array}{c}\text { Standard } \\
\text { deviation } S \\
{\left[\mathrm{~g} / \mathrm{m}^{3}\right]}\end{array}$ & $\begin{array}{c}\text { Variation } \\
\text { coefficient } V \\
\text { [\%] }\end{array}$ \\
\hline $\begin{array}{l}\text { Iron } \mathrm{Fe}^{++} \text {content } \\
{\left[\mathrm{g} \mathrm{Fe}^{++} / \mathrm{m}^{3}\right]}\end{array}$ & $\begin{array}{c}277200^{*} \\
293480^{* *} \\
51840^{* * *}\end{array}$ & $\begin{array}{l}0.0502 \\
0.0728 \\
0.0500\end{array}$ & $\begin{array}{l}0.9166 \\
5.7107 \\
0.4100\end{array}$ & $\begin{array}{l}0.2573 \\
0.8409 \\
0.1900\end{array}$ & $\begin{array}{l}0.1510 \\
1.1265 \\
0.1200\end{array}$ & $\begin{array}{c}58.70 \\
133.97 \\
64.10\end{array}$ \\
\hline $\begin{array}{l}\text { Manganese } \mathrm{Mn}^{++} \text {content } \\
{\left[\mathrm{g} \mathrm{Mn}^{++} / \mathrm{m}^{3}\right]}\end{array}$ & $\begin{array}{l}277200^{*} \\
293480^{* *} \\
51840^{* * *}\end{array}$ & $\begin{array}{c}0.1905 \\
0.2290 \\
0.35\end{array}$ & $\begin{array}{c}1.2753 \\
0.7883 \\
0.61\end{array}$ & $\begin{array}{c}0.3391 \\
0.3522 \\
0.46\end{array}$ & $\begin{array}{c}0.0781 \\
0.0788 \\
0.09\end{array}$ & $\begin{array}{l}23.05 \\
22.37 \\
18.75\end{array}$ \\
\hline $\begin{array}{l}\text { Ammonium ion } \mathrm{NH}_{4}^{+} \text {content } \\
{\left[\mathrm{g} \mathrm{NH}_{4}^{+} / \mathrm{m}^{3}\right]}\end{array}$ & 277200 & 0.0822 & 04543 & 0.1512 & 0.0669 & 44.22 \\
\hline $\begin{array}{l}\text { Nitrate ion } \mathrm{NO}_{3}^{-} \text {content } \\
{\left[\mathrm{g} \mathrm{NO}_{3}^{-} / \mathrm{m}^{3}\right]}\end{array}$ & 277200 & 0.1746 & 3.2647 & 0.8802 & 0.4387 & 49.84 \\
\hline $\begin{array}{l}\text { Phosphate } \mathrm{PO}_{4}^{-3} \text { content } \\
{\left[\mathrm{g} \mathrm{PO}_{4}^{-3} / \mathrm{m}^{3}\right]}\end{array}$ & 277200 & 0.0791 & 0.1800 & 0.1052 & 0.0125 & 11.92 \\
\hline $\begin{array}{l}\text { Organic coal C (OWO) content } \\
{\left[\mathrm{g} \mathrm{C}^{\mathrm{m}} \mathrm{m}^{3}\right]}\end{array}$ & 277200 & 0.7328 & 1.3479 & 1.0883 & 0.0975 & 8.96 \\
\hline $\begin{array}{l}\text { Temperature }\left[{ }^{\circ} \mathrm{C}\right] \\
\text { [degrees] }\end{array}$ & 277200 & 7.3378 & 9.6972 & 7.9949 & 0.4416 & 5.52 \\
\hline $\mathrm{pH}$ & $\begin{array}{l}277200^{*} \\
293480^{* * *}\end{array}$ & $\begin{array}{l}6.0853 \\
6.0581\end{array}$ & $\begin{array}{l}6.7652 \\
7.3623\end{array}$ & $\begin{array}{l}6.5134 \\
6.6263\end{array}$ & $\begin{array}{l}0.1976 \\
0.2366\end{array}$ & $\begin{array}{l}3.03 \\
3.57\end{array}$ \\
\hline
\end{tabular}

Iron $\mathrm{Fe}^{++}$, manganese $\mathrm{Mn}^{++}$(year 2011*; years 2011-2012**; years 1977-2011**); pH (year 2011, years 2011-2012) ${ }^{* *}$; ammonium ion $\mathrm{NH}_{4}^{+}$, nitrate ion $\mathrm{NO}_{3}^{-}$, phosphate ion $\mathrm{PO}_{4}^{-3}$, content of organic coal $\mathrm{C}(\mathrm{OWO})$, temperature ${ }^{\circ} \mathrm{C}\left(\right.$ year $2011^{*}$ ).

Table 11. Global statistics of estimation standard deviation $\sigma_{k}$ of quality parameters of underground water;

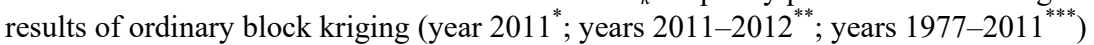

\begin{tabular}{|c|c|c|c|c|c|c|}
\hline $\begin{array}{c}\text { Parameter } \\
\text { analyzed }\end{array}$ & $\begin{array}{c}\text { Number } \\
\text { of grid nodes } n\end{array}$ & $\begin{array}{c}\text { Minimal } \\
\text { value } X_{\min } \\
{\left[\mathrm{g} / \mathrm{m}^{3}\right]}\end{array}$ & $\begin{array}{c}\text { Maximal } \\
\text { value } X_{\max } \\
{\left[\mathrm{g} / \mathrm{m}^{3}\right]}\end{array}$ & $\begin{array}{c}\text { Average } \\
\text { value } \bar{X} \\
{\left[\mathrm{~g} / \mathrm{m}^{3}\right]}\end{array}$ & $\begin{array}{c}\text { Standard } \\
\text { deviation } S \\
{\left[\mathrm{~g} / \mathrm{m}^{3}\right]}\end{array}$ & $\begin{array}{c}\text { Variation } \\
\text { coefficient } V \\
{[\%]}\end{array}$ \\
\hline $\begin{array}{l}\text { Iron } \mathrm{Fe}^{++} \text {content } \\
{\left[\mathrm{g} \mathrm{Fe}^{++} / \mathrm{m}^{3}\right]}\end{array}$ & $\begin{array}{l}277200^{*} \\
293480^{* *} \\
51840^{* * *}\end{array}$ & $\begin{array}{l}0.0104 \\
0.1930 \\
0.0600\end{array}$ & $\begin{array}{l}0.3930 \\
2.5034 \\
0.0700\end{array}$ & $\begin{array}{l}0.2964 \\
1.5413 \\
0.0600\end{array}$ & $\begin{array}{l}0.0935 \\
0.7010 \\
0.0000\end{array}$ & $\begin{array}{c}31.54 \\
45.48 \\
6.87\end{array}$ \\
\hline $\begin{array}{l}\text { Manganese } \mathrm{Mn}^{++} \text {content } \\
{\left[\mathrm{g} \mathrm{Mn}^{++} / \mathrm{m}^{3}\right]}\end{array}$ & $\begin{array}{l}277200^{*} \\
293480^{* *} \\
51840^{* * *}\end{array}$ & $\begin{array}{l}0.0088 \\
0.0616 \\
0.1300\end{array}$ & $\begin{array}{l}0.3500 \\
0.2993 \\
0.2200\end{array}$ & $\begin{array}{l}0.2464 \\
0.2325 \\
0.1800\end{array}$ & $\begin{array}{l}0.0863 \\
0.0740 \\
0.0200\end{array}$ & $\begin{array}{l}35.02 \\
31.84 \\
13.54\end{array}$ \\
\hline $\begin{array}{l}\text { Ammonium ion } \mathrm{NH}_{4}^{+} \text {content } \\
{\left[\mathrm{g} \mathrm{NH}_{4}^{+} / \mathrm{m}^{3}\right]}\end{array}$ & 277200 & 0.0161 & 0.1490 & 0.0940 & 0.0427 & 45.43 \\
\hline $\begin{array}{l}\text { Nitrate ion } \mathrm{NO}_{3}^{-} \text {content } \\
{\left[\mathrm{g} \mathrm{NO}_{3}^{-} / \mathrm{m}^{3}\right]}\end{array}$ & 277200 & 0.1818 & 1.0223 & 0.8145 & 0.2574 & 31.61 \\
\hline $\begin{array}{l}\text { Phosphate ion } \mathrm{PO}_{4}^{-3} \text { content } \\
{\left[\mathrm{g} \mathrm{PO}_{4}^{-3} / \mathrm{m}^{3}\right]}\end{array}$ & 277200 & 0.0220 & 0.0445 & 0.0405 & 0.0060 & 14.71 \\
\hline $\begin{array}{l}\text { Organic coal C (OWO) content } \\
{\left[\mathrm{gC} / \mathrm{m}^{3}\right]}\end{array}$ & 277200 & 0.7328 & 1.3479 & 1.0883 & 0.0975 & 8.96 \\
\hline $\begin{array}{l}\text { Temperature }\left[{ }^{\circ} \mathrm{C}\right] \\
\text { [degrees] }\end{array}$ & 277200 & 0.0554 & 0.7222 & 0.3620 & 0.1985 & 54.85 \\
\hline $\mathrm{pH}$ & $\begin{array}{l}277200^{*} \\
293480^{* *}\end{array}$ & $\begin{array}{l}0.0639 \\
0.0293\end{array}$ & $\begin{array}{l}0.2429 \\
0.4257\end{array}$ & $\begin{array}{l}0.1421 \\
0.2580\end{array}$ & $\begin{array}{l}0.0537 \\
0.1271\end{array}$ & $\begin{array}{l}37.79 \\
49.26\end{array}$ \\
\hline
\end{tabular}

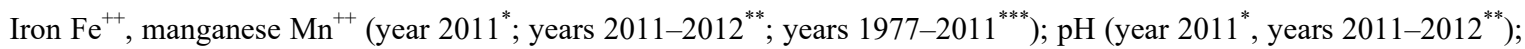
ammonium ion $\mathrm{NH}_{4}^{+}$, nitrate ion $\mathrm{NO}_{3}^{-}$, phosphate ion $\mathrm{PO}_{4}^{-3}$ content of organic coal C (OWO), temperature ${ }^{\circ} \mathrm{C}$ (year $2011^{*}$ ). 
3 piezometers) (Table 10). The coefficient of variation $V$ proves extremely large changes in the content of iron $\mathrm{Fe}^{++}$in the area of Kłodzko.

If the basis for calculation is the data associated with a longer period of years 1977-2011, max value $Z^{*}$ exceeds the permissible value for this element, while the average value $Z^{*}(\bar{X})$ reaches a similar level, and the coefficient $V$ indicates a large variation in the iron $\mathrm{Fe}^{++}$content (Table 10).

The min and max estimated values $Z^{*}$ and mean averages $Z^{*}(\bar{X})$ of manganese $\mathrm{Mn}^{++}$content exceed the permitted value of this parameter, regardless of the variant considered in the analysis ( 14 wells +3 piezometers, the years 1977-2011) (Table 10). The variation coefficients $V$ indicate low variation of $\mathrm{Mn}^{++}$ content, a slightly higher for variant of wells $14+3$ piezometers.

In the case of potential $\mathrm{pH}$ higher max values of $Z^{*}$ and average $\bar{X}$ were obtained on the basis of data coming from 14 wells and 3 piezometers (Table 10). The max values of $Z^{*}$ for $\mathrm{pH}$ and coefficient $V$ are a little higher for this variant of calculations.

Analysing the values of variation coefficients $V$ of estimation standard deviation $\sigma_{k}$ one can notice that the highest coefficients $V$ characterize ammonium ion $\mathrm{NH}_{4}^{+}$content and temperature ${ }^{\circ} \mathrm{C}$, followed by $\mathrm{pH}$, $\mathrm{Fe}^{++}$content, $\mathrm{Mn}^{++}$content, $\mathrm{NO}_{3}^{-}$and $\mathrm{NH}_{4}^{+}$anion content (Table 11).

The high values of coefficients $V$ are due to, among other things, the short-term changes in the investigated parameters, evident in the vertical direction (along the wells depth), and difficulties in selecting appropriate analytical functions for the directional semivariograms.

The highest values of min and max of st. deviation of $\sigma_{k}$, as well as, the average value $\bar{X}$, st. deviation and coefficient of variation $V$ for iron $\mathrm{Fe}^{++}$content were obtained for the variant of calculation, comprising 14 wells and 3 piezometers (Table 11). The lowest values of the relevant basic statistics were obtained for data related to the years of 1977-2011.

In the case of the $\mathrm{Mn}^{++}$content the lowest values of max $Z^{*}$, average $\bar{X}$ and coefficient of variation $V$, st. deviation of estimation $\sigma_{k}$ characterize the results of the calculations conducted for data connected with the period of years 1977-2011 (Table 11).

The max value $Z^{*}$, average $\bar{X}$, st. deviation $\sigma_{k}$ and coefficient $V$ for $\mathrm{pH}$ are higher if the calculations have been performed taking data from 14 wells +3 piezometers into account (Table 11).

The results of the estimation based on the data for the 14 wells (first variant of the study) and next 14 wells +3 piezometers (second variant of the study), by means of ordinary kriging are evidence of the existence of levels of elevated values of the different underground water quality parameters (Figs. 23-28) [6], [9], [10], [13], [14].

In the first variant of the calculations the highest averages $Z^{*}$ of $\mathrm{Fe}^{++}$content in the underground water occur in the SW part of the water intake area and within the elevation interval of $290.55-291.45 \mathrm{~m}$ a.s.l. (the levels 50 and 60 ), while the $\mathrm{Fe}^{++}$content maximum $\left(0.70-0.90 \mathrm{gFe}^{++} / \mathrm{m}^{3}\right)$ occurs at level 50 [6]. In the second variant of the study we notice two levels with the increased averages $Z^{*}$ of $\mathrm{Fe}^{++}$content, lower level more distinct outlined $(\sim 290 \mathrm{~m}$ a.s.l.) and upper weaker ( $293 \mathrm{~m}$ a.s.1.) $\left(4.1-4.6 \mathrm{gFe}^{++} / \mathrm{m}^{3}\right.$ at level 60 with surrounding envelope of $\mathrm{Fe}^{++}$contents to $3.6-4.1 \mathrm{gFe}^{++} / \mathrm{m}^{3}$ and $3.1-3.6 \mathrm{gFe}^{++} / \mathrm{m}^{3}$ (S and $\mathrm{SW}$ part of area) (Fig. 23).

In the first variant of the studies the maximum estimated averages $Z^{*}$ of $\mathrm{Mn}^{++}$content in the underground water are found mostly in the SW part of the water intake area within the elevation interval of 290.55-291.45 m a.s.1., while the $\mathrm{Mn}^{++}$content maximum $\left(0.80-0.95 \mathrm{gMn}^{++} / \mathrm{m}^{3}\right)$ is observed at level 60 [6]. In the second variant of the analysis the level with elevated averages $Z^{*}$ is more distinct delineated ( $293 \mathrm{~m}$ a.s.l.) $\left(0.76-0.81 \mathrm{gMn}^{++} / \mathrm{m}^{3}\right.$ at level 60 , with an envelope of $\mathrm{Mn}^{++}$contents to $0.66-0.76 \mathrm{gMn}^{++} / \mathrm{m}^{3}$ ) (central and SW part of area ) (Fig. 24).

The maximum estimated averages $Z^{*}$ of ammonium ion $\mathrm{NH}_{4}^{+}$content $\left(0.35-0.43 \mathrm{~g} \mathrm{NH}_{4}^{+} / \mathrm{m}^{3}\right)$ in the underground water occur mostly in the SW part of the water intake area at the elevation of $290.55 \mathrm{~m}$ a.s.l., at level 50 (Fig. 25).

The maximum estimated averages $Z^{*}$ of nitrate anion $\mathrm{NO}_{3}^{-}$content $\left(2.4-3.1 \mathrm{~g} \mathrm{NO}_{3}^{-} / \mathrm{m}^{3}\right)$ in the underground water occur mostly in the NW part of the water intake area within the elevation interval of 291.45$292.36 \mathrm{~m}$ a.s.1., at levels 60 and 70 (Fig. 26).

The maximum estimated averages $Z^{*}$ of phosphate anion $\mathrm{PO}_{4}^{-3}$ content $\left(0.15-0.18 \mathrm{~g} \mathrm{PO}_{4}^{-3} / \mathrm{m}^{3}\right)$ in the underground water occur mostly in the $\mathrm{S}$ and SW parts and less often in the E and SE parts of the water intake area at the elevation of $290.55 \mathrm{~m}$ a.s.1., at level 50 (Fig. 27).

The maximum estimated averages $Z^{*}$ of total organic carbon $\mathrm{C}\left(1.25-1.35 \mathrm{gC} / \mathrm{m}^{3}\right)$ in the underground water occur mostly in the SW and S parts and less often in the E and SE parts of the water intake area at the elevation of $291.45 \mathrm{~m}$ a.s.l., at level 60 [6], [14]. High averages $Z^{*}$ of carbon $\mathrm{C}\left(1.20-1.27 \mathrm{gC} / \mathrm{m}^{3}\right)$ were also found at levels $30(288.73 \mathrm{~m}$ a.s.l.) and 50 (290.55 m a.s.1.). 
In the first variant of the studies the maximum estimated averages $Z^{*}$ of underground water $\mathrm{pH}$ occur in the $\mathrm{N}$ and $\mathrm{S}$ parts of the water intake area at elevations of 290.55 and $292.36 \mathrm{~m}$ a.s.l. - at levels 50 and 70 (6.63-6.73 and $6.53-6.63 \mathrm{pH}$ ) [6]. In the second variant of analysis two levels of elevated averages $Z^{*}$ of $\mathrm{pH}$ are observed at levels 60 and 70, more outlined upper level with values ranging from: 7.2-7.3 and 6.9-7.2 (293 m a.s.1.) and lower weakly delineated ( $290 \mathrm{~m}$ a.s.1.), with values of $\mathrm{pH}$ 6.9-7.2 (central and SW part of area) (Fig. 28).

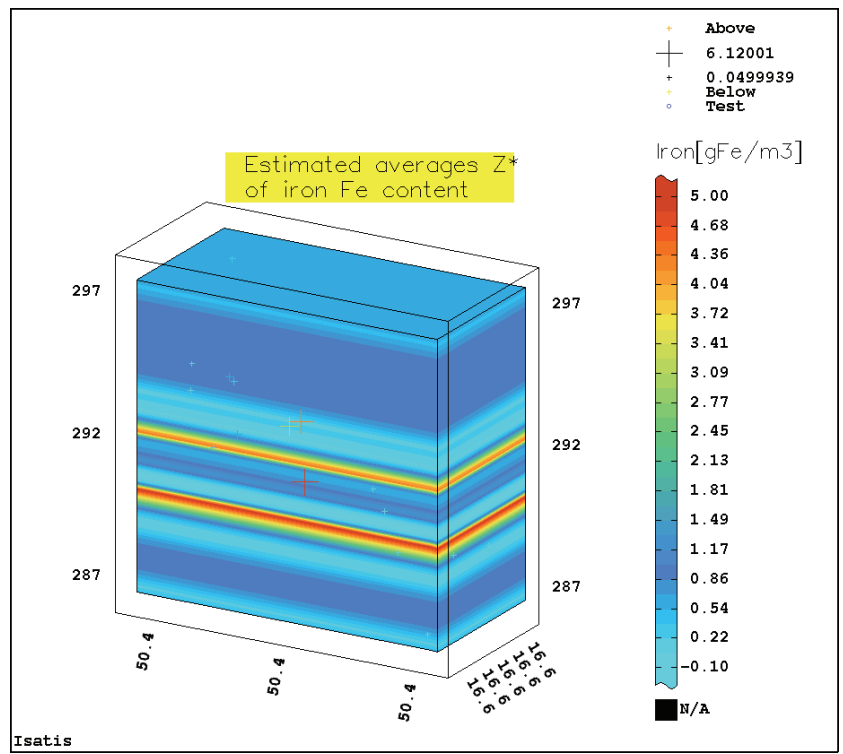

Fig. 23. Block diagram of estimated averages $Z^{*}$ distribution of iron $\mathrm{Fe}^{++}$content $\left[\mathrm{gFe}^{++} / \mathrm{m}^{3}\right]$ in underground water in Kłodzko intake area; 14 wells +3 piezometers

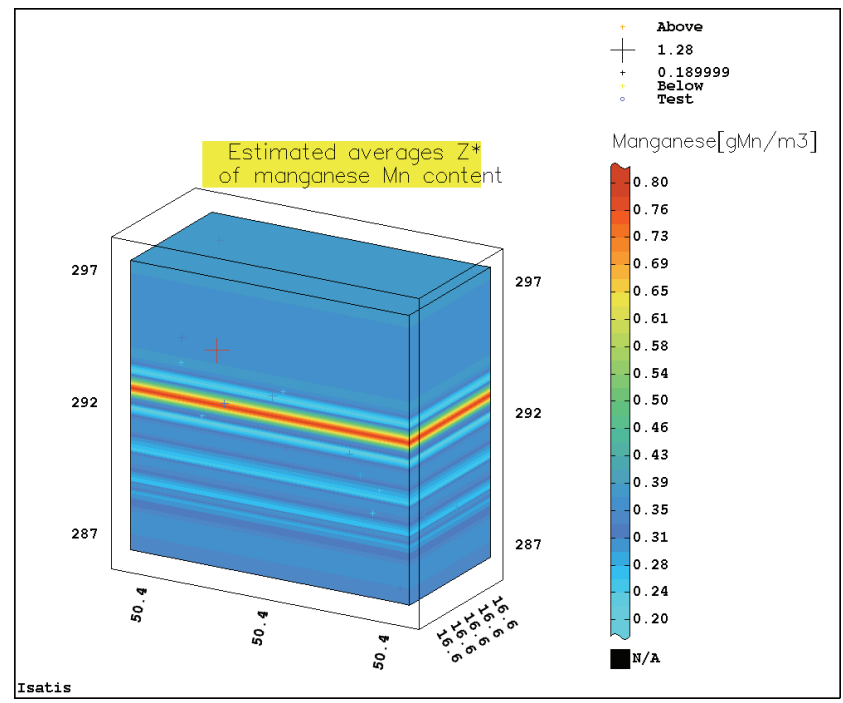

Fig. 24. Block diagram of estimated averages $Z^{*}$ distribution of manganese $\mathrm{Mn}^{++}$content $\left[\mathrm{gMn}^{++} / \mathrm{m}^{3}\right]$ in underground water in Kłodzko intake area; 14 wells +3 piezometers

The maximum averages $Z^{*}$ of underground water temperature ${ }^{\circ} \mathrm{C}\left(9.1-9.3{ }^{\circ} \mathrm{C}\right.$ and $\left.9.3-9.5^{\circ} \mathrm{C}\right)$ occur in the N, NE and S parts of the intake area at the elevation of $290.55 \mathrm{~m}$ a.s.1., at level 50 [6], [14].

The results of the estimation based on the data for the 14 wells and the 3 piezometers, by means of ordinary kriging, indicate the occurrence of depth levels with elevated (increased) values of the three water quality parameters, thereby extending and specifying the knowledge of their variation for Kłodzko water intake area [6], [10], [13], [14].

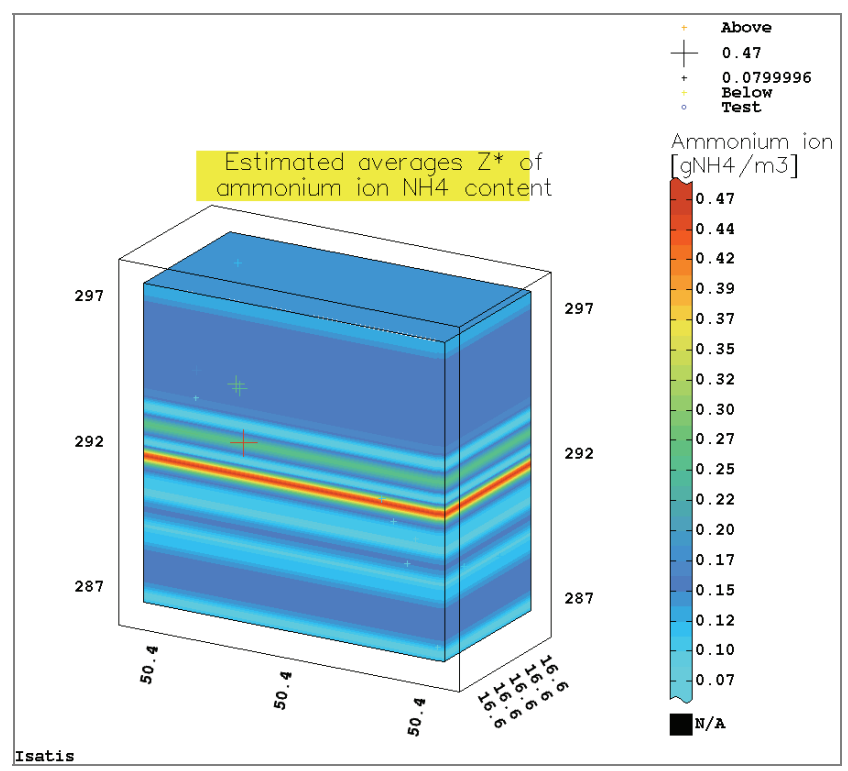

Fig. 25. Block diagram of estimated averages $Z^{*}$ distribution of ammonium ion $\mathrm{NH}_{4}^{+}$content $\left[\mathrm{g} \mathrm{NH}_{4}^{+} / \mathrm{m}^{3}\right]$ in underground water in Kłodzko intake area; 14 wells

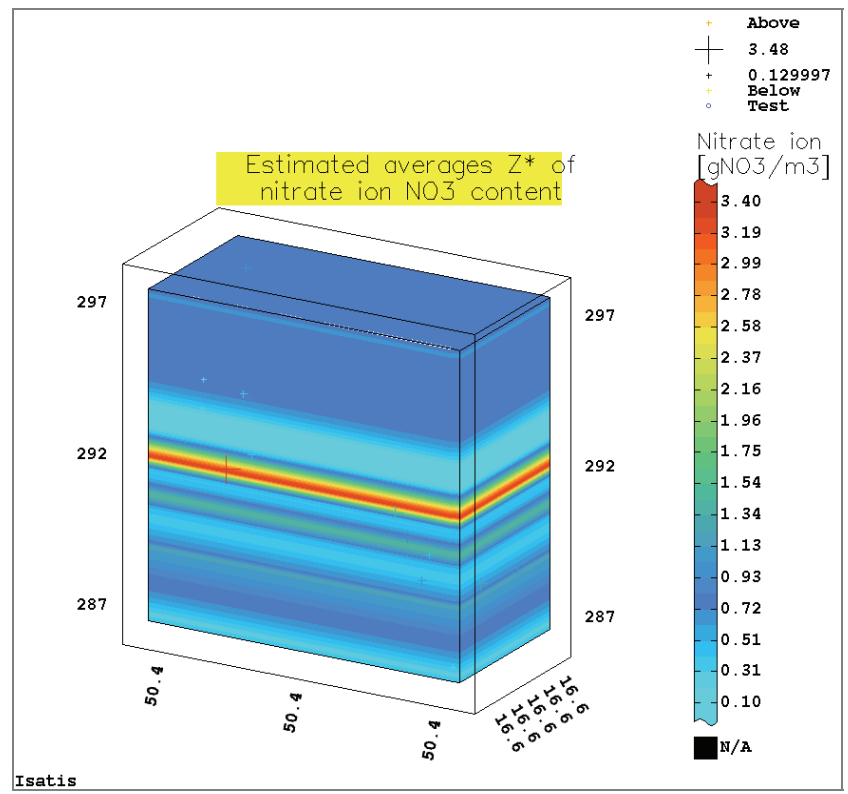

Fig. 26. Block diagram of estimated averages $Z^{*}$ distribution of nitrate ion content $\left[\mathrm{g} \mathrm{NO}_{3}^{-} / \mathrm{m}^{3}\right]$ in underground water in Kłodzko intake area; 14 wells 


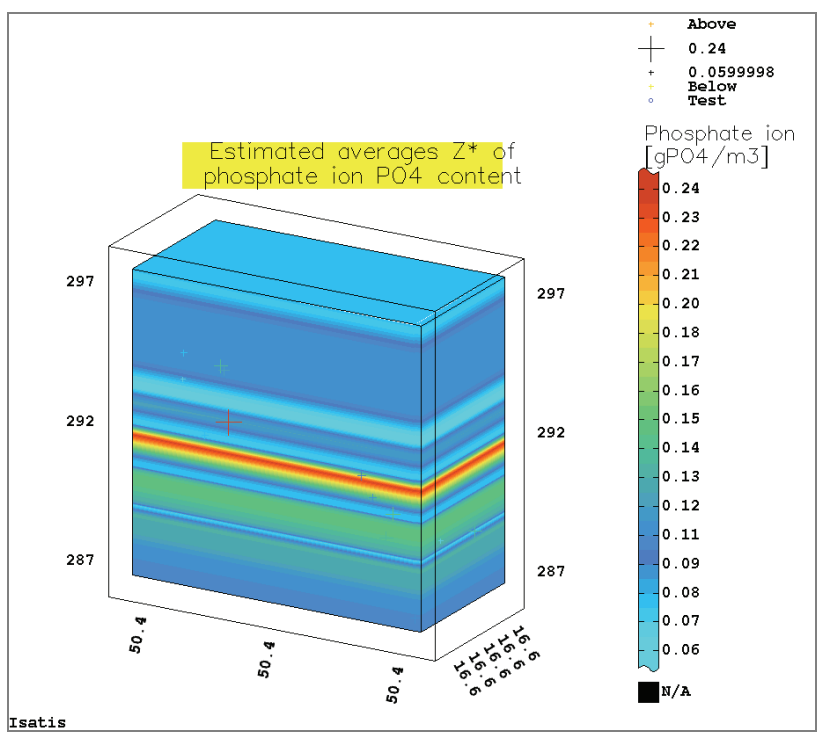

Fig. 27. Block diagram of estimated averages $Z^{*}$ distribution of phosphate anion content $\left[\mathrm{g} \mathrm{PO}_{4}^{-3} / \mathrm{m}^{3}\right]$ in underground water in Kłodzko intake area; 14 wells

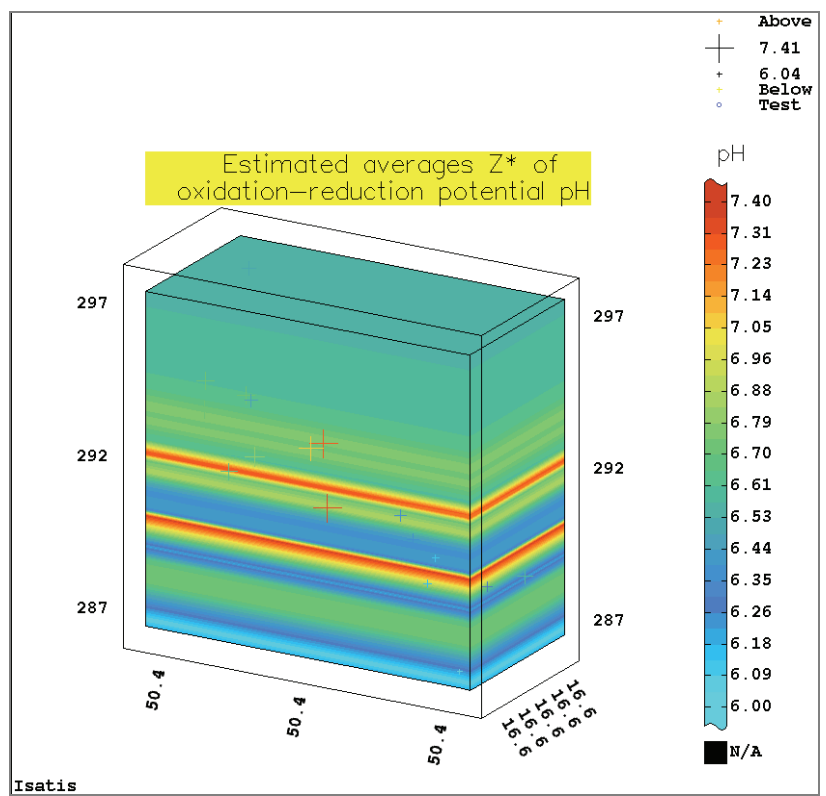

Fig. 28. Block diagram of estimated averages $Z^{*}$ distribution of oxidation-reduction potential $\mathrm{pH}$ in underground water in Kłodzko intake area; 14 wells +3 piezometers

\section{RECAPITULATION}

The levels of pollution of groundwater aquifers were determined and characterized in area around the town of Kłodzko and in the vertical profile of the wells analysed, according to the depth of the wells.

It was found that the greatest impact on groundwater quality had the kind of land development located near the wells. At the most important values of indicators of chemical composition, found in the underground water in some wells, it can be influenced the proximity of land used for agriculture and the smallest output (efficiency) of these wells.

For the region of Kłodzko under study, sources of the increased contents of $\mathrm{Fe}^{++}$and $\mathrm{Mn}^{++}$, in lesser degree of $\mathrm{NH}_{4}^{+}$, are connected, first of all with agriculture, i.e., farming, improper fertilization of agricultural land and also caused by the factors of geochemical origin (rockbase in Kłodzko water intake area). The $\mathrm{Fe}^{++}$and $\mathrm{Mn}^{++}$ compounds from the rocks and the soil are leached into the deep waters. The $\mathrm{Fe}^{++}$may come from metallurgical wastes while the $\mathrm{Mn}^{++}$may originate from the mining, smelting, ceramic and artificial fertilizer industries. The elevated content of $\mathrm{Fe}^{++}$and $\mathrm{Mn}^{++}$can be derived from weathering of bedrock, namely of greenstone rocks representing Old Paleozoic.

The adopted (3D) geostatistical model enables researchers and practitioners to determine averages $Z^{*}$ (together with estimation standard deviation $\sigma_{k}$ ) in the individual nodes of the 3D grid covering the area of the Kłodzko Catchment and at selected points of the area. The content of the databases used to construct the $3 \mathrm{D}$ model enables one to estimate averages $Z^{*}$, modelling of their variation and so to analyse the quality of underground water in an area defined by researchers and users.

\section{CONCLUSION}

A hydrogeochemical model of the Kłodzko Catchment in the Kłodzko town underground water intake area was developed. Thanks to the 3D geostatistical model of the variation in water quality parameters it was possible to precisely characterize this variation in the whole water intake area under study consideration in the years 2011 2012, analysed for the years 1977-2012. Spatial analyses showed different behaviours of the water quality parameters and certain regularities in their variability

Mostly there can be noticed a very strong shortperiodic variation in semivariogram function $\gamma(h)$ values of water quality parameters, expressed along the wells depth, rarely more distinct or even directional variation.

The essential water quality parameters are: $\mathrm{Fe}^{++}$ content, $\mathrm{Mn}^{++}$content, nitrate anion $\mathrm{NO}_{3}^{-}$content and ammonium anion $\mathrm{NH}_{4}^{+}$content. These parameters should be continuously monitored out of concern for the health of the local population (of inhabitants, animals and plants). 
Based on the estimation carried out using ordinary kriging and data for the 14 wells and for the 14 wells and the 3 piezometers it was possible to identify levels with elevated water quality parameters. The maximum averages $Z^{*}$ of the parameters would be found mostly at levels 50 and 60 and less often at levels 60 and 70, within the terrain elevation range of 290.55-292.36 m a.s.l., mostly in the SW part and less often in the N, NW and NE parts of the Kłodzko water intake area.

Owing to the enrichment of the databases with the results of the chemical determinations of $\mathrm{Fe}^{++}, \mathrm{Mn}^{++}$and $\mathrm{pH}$ carried out for the 3 piezometers, it became possible to obtain a more accurate picture of the concentration of the elements (14 wells +3 piezometers) and so to verify the results obtained previously only on the basis of the data for the 14 wells, chosen from the 22 wells.

The results of the spatial analyses carried out for the Kłodzko water intake area in the years 2011-2012 add to the previous picture of the variation in the water quality parameters, related to years 1977-1999.

The results of the geostatistical studies can well be used in further spatial analyses to describe the state of water quality.

\section{REFERENCES}

[1] Armstrong M., Basic Linear Geostatistics, Springer, Berlin $1998,153$.

[2] Biedroń I., Świderska-Bróż M., Traczewska T., Trusz-ZDYBeK A., NAMYSŁOWSKA-WILCZYŃSKa B., WOLSKA M., Preliminary assessment of the quality of underground waters in a selected area of the Kłodzko Valley, Journal: Instal, Teoria i Praktyka w Instalacjach, monthly, 2013, 6(341), 41-44, Warszawa, (in Polish).

[3] IsaAKs E.H., SRIVASTAVA R.M., An Introduction to Applied Geostatistics, OUP, N.Y. 1989, 561.

[4] MąDRAla M., Hydrogeochemical valorization of environments of river valleys for the needs of underground waters exploitation, Współczesne Problemy Hydrogeologii, Wrocław 2001, 357-364.

[5] NAMYSŁowsKA-WilcZyŃSKA B., Geostatystyka. Teoria i Zastosowania. Monography, Oficyna Wydawnicza Politechniki Wrocławskiej, Wrocław 2006, 356.

[6] NAMYSŁOWSKA-WiLCZYŃSKA B., Hydrogeochemical model for underground water intake area in Kłodzko, (in Polish). SPR series report No. 1/2012, Institute of Geotechnics and Hydrotechnics at Wrocław University of Technology, March 2012. Text and Attachment. Development Project No. 09-0036 - 10/2011, funded by the National Centre for Research and Development, entitled "The Technology of the biochemical remediation and storage of surface waters in underground hydrogeological structures for municipal water intakes in river valleys" (2012-2016); Research task 3 entitled "Identification and hydrogeochemical models of the Kłodzko Drainage area", p. 279, Wrocław 2012.

[7] NAMYSŁOWSKA-WILCZYŃSKA B., Geostatistical hydrogeochemical $3 D$ model for Kłodzko underground water intake area. Part I. Estimation of basic statistics on quality parameters of underground waters, Studia Geotechnica et Mechanica, Wrocław, 2013, Vol. XXXV, No. 1, 157-181.
[8] NAMYSŁOWSKA-WILCZYŃSKA B., Estimation of underground water quality parameters for the water intake area near Kłodzko by means of ordinary kriging, (in Polish), Monograph, XX KK KOWBAN' 2013 National Conference "Computer Support of Research", Polanica Zdrój, Poland, 23-25.10.2013, 215-225.

[9] NAmysŁowska-WilczyŃska B., Geostatistical studies of space-time variation in underground water quality parameters in Kłodzko water intake area (SW part of Poland); 10th Conference on Geostatistics for Environmental Applications, 9-11 July 2014, Paris, France, Proceedings GeoENV 2014, July 9-11, Paris 2014, Full paper included in electronic version; Book of Abstracts, 133-134. Mines Paris Tech. Sciences de la Terre et de/Environment. Presses des Mines - Transvalor, Paris, France. Nicolas Jeannee, Thomas Romary (editors).

[10] NAMYSŁOWSKA-WiLCZYŃSKA B., Geostatistical studies of space-time variation in underground water quality parameters in Kłodzko water intakes area (SW part of Poland), X International Conference on Geostatistics for Environmental Applications, GeoENV2014, Paris, France, 9-11 July 2014, Session Geostatistical Theory \& New Methodologies. Poster, Format A0 (Internet).

[11] NAMYSŁOWSKA-WILCZYŃSKA B., Geostatistical characteristic of space-time variation in quality parameters in Kłodzko water supply system (SW part of Poland), European Geosciences Union General Assembly, 2015, Vienna, Austria, 12-17 April 2015. Paper presented in the Session: Geostatistics for spatio-temporal analysis of hydrological events and environmental problems (13.04.2015). Geophysical Research Abstracts, Vol. 17, EGU2015-15693-2, 2015 EGU General Assembly 2015.

[12] NAMYSŁOWSKA-WILCZYŃSKA B., Geostatistical studies of space-temporal variation in selected quality parameters in Kłodzko water supply system (SW part of Poland), Journal of Geological Resource and Engineering, 2015, Vol. 3, No. 2, USA, 57-81.

[13] NAMYSŁOWSKA-WiLCZYŃSKA B., Space-Temporal Variation in Underground Water Some Quality Parameters in Kłodzko Water Intake Area using Statistical and Geostatistical Methods (SW Part of Poland), Journal of Geological Resource and Engineering, 2016, Vol. 4, No. 3, 105-124.

[14] NAmysŁowska-WilczyŃsKa B., Geostatistical Characteristic of Space-Time variation in Selected Underground Water Quality Parameters in Kłodzko Water Intake Area (SW Part of Poland), European Geosciences Union - General Assembly 2016, Austria, Center Vienna, Austria 1722 April 2016. Geophysical Research Abstracts, Vol. 18, EGU 2016-9019, 2016 EGU General Assembly 2016. Poster paper presented in the Session: Hydrological Sciences Hydroinformatics HS HS3.2/NH1.26 Spatiotemporal and/or geostatistical analysis of hydrological events, extremes, and related hazards (Thursday, 21 April 2016, A. 133).

[15] Software User's Guide, ISATIS, 2015, Isatis version 2015, Ecole des Mines de Paris, Centre de Geostatistique, Fontainebleau, Geovariances, Avon Cedex, France, 2015.

[16] Wackernagel H., Multivariate Geostatistics: an Introduction with Applications. 2nd ed. Springer, Berlin 1998.

[17] Geostatististical Glossary and Multilingual Dictionary, R.A. Olea (Ed.), Intern. Association for Mathematical Geology Studies in Mathematical Geology, Oxford University Press, New York, Oxford, 1991. p. 177. 